\title{
Incongruent patterns of genetic connectivity among four ophiuroid species with differing coral host specificity on North Atlantic seamounts
}

\author{
Walter Cho and Timothy M. Shank* \\ Biology Department
}

Woods Hole Oceanographic Institution

Woods Hole, MA 02543

*corresponding author

234 Redfield Laboratory

Biology Department

Woods Hole Oceanographic Institution

Woods Hole, MA 02543

Tel: 508-289-3392

Email: tshank@whoi.edu 


\section{Abstract}

Seamounts are considered to play a defining role in the evolution and diversity of marine fauna, acting as "stepping-stones" for dispersal, regional centers of genetic isolation and speciation, and refugia for deep-sea populations. This study focused on the patterns of dispersal and genetic connectivity of four seamount ophiuroid species (Asteroschema clavigera, Ophiocreas oedipus, Ophioplinthaca abyssalis and Ophioplinthaca chelys) displaying differing levels of associative (epifaunal) specificity to cold-water coral hosts inhabiting the New England and Corner Rise Seamount chains, and Muir Seamount in the Northwestern Atlantic. Analyses of mt16S and mtCOI revealed evidence for recent population expansion and high gene flow for all four species. However, species-specific genetic differentiation was significant based on seamount region and depth. Significant differences were found among regional seamount groups for $A$. clavigera, within seamount regions and seamounts for $O$. chelys, among $250 \mathrm{~m}$ depth intervals for A. clavigera, among $100 \mathrm{~m}$ depth intervals for O. oedipus, and there were indications of isolation by distance for $A$. clavigera and $O$. oedipus. In addition, $A$. clavigera and $O$. oedipus, broadcast spawners with high fidelity to specific coral hosts, displayed predominantly westward historical migration, while the ophioplinthacids, with lower host-specificity, displayed predominantly eastward migration. No congruent patterns of historical migration were evident among species and seamounts, yet these patterns can be correlated with species-specific host specificity, specific depth strata, and dispersal strategies. Conservation efforts to protect seamount ecosystems should promote multi-species approaches to genetic connectivity, and consider the impact of the "dependence" of biodiversity on host fauna in these vulnerable marine ecosystems. 


\section{Introduction}

The mechanisms of faunal dispersal are key unknowns in understanding the connective processes that shape biogeography, regional endemism, biodiversity, and approaches to protect vulnerable marine ecosystems in the deep sea. Seamounts, mountains that rise more than 1000 $\mathrm{m}$ from the surrounding seafloor but are not emergent above the sea surface (Staudigel et al. 2010), can be considered dynamic agents where these processes are pronounced. Often formed by mantle plumes associated with mid-plate hot spots, mid-ocean ridge volcanism, and plate tectonic shifts (Fryer and Fryer 1987; Epp and Smoot 1989; Batiza 2001), seamounts have been conservatively estimated at more than 800 in the Atlantic, 30,000-50,000 in the Pacific, and more than 100,000 ( $>1 \mathrm{~km}$ elevation) throughout the world's oceans (Epp and Smoot 1989; Rogers

1994; Rogers 2004; Wessel et al. 2010), and collectively cover an area more than 28 million km² (Etnoyer et al., 2010). As such, they may fundamentally impact the evolutionary processes of life in the deep ocean.

Functionally, seamounts provide elevated hard-substrate habitats above a typically sedimented deep sea, and often in the form of chains perpendicular to coastlines and mid-ocean ridges. Thus, they possess the potential to play a significant role in facilitating the dispersal and maintenance of faunal species, isolating populations, promoting speciation, and driving the biogeographic structure of the deep ocean (e.g., Hamilton 1956; Hubbs 1959; Rogers 1994, Shank 2010a). Several studies have found high levels of seamount endemism, suggesting that seamounts act as foci of genetic isolation, speciation, and refugia for relict populations (Rogers 2004; Clark et al. 2010). Wilson and Kaufman (1987) estimated that 15\% of the invertebrate fauna on seamounts were endemic. Higher endemism levels of 16-33\% were found among invertebrate species on the seamounts off Tasmania (Koslow et al. 2001), while 29-34\% of the 
macro- and megafauna of seamounts in the Tasman Sea and southeast Coral Sea were potential seamount endemics (Richer de Forges et al. 2000). Even higher rates were found on the Nasca and Sala-y-Gomez seamount chains off the coast of Chile, which had apparent invertebrate endemism levels of 52\% (Parin et al. 1997). It is widely noted that results of such endemism studies are highly sensitive to regional sampling efforts and methods, with difficulty distinguishing between true local endemicity and sampling biases, particularly those arising from the occasional collection of rare but widespread species (O'Hara 2007; McClain et al. 2009; Clark et al. 2010).

In contrast to the aforementioned morphological studies, genetic studies of bamboo coral species on seamounts in the southwest and northwest Pacific Ocean (Smith et al. 2004a) and of octocoral and antipatharian seamount populations in the northwest Atlantic (Thoma et al. 2009) have revealed a notable lack of endemism. Endemism infers the isolation of populations and species on evolutionary and ecological timescales. In this regard, seamounts can be considered "isolated" only if significant historical or modern day genetic exchange can be shown to be significantly restricted (and not simply geographically distant) (Shank 2010a). To infer the "isolating" processes responsible for structuring seamount populations, genetic studies have examined the intra-specific distribution and connectivity of populations on different seamounts with varying results. The majority of studies targeting fish and larger mobile fauna have revealed little to no genetic or geographical isolation between seamounts. For example, investigations of polymorphic allozymes in the fish Hyperoglyphe antarctica and three mitochondrial gene regions in the fish Pseudopentaceros wheeleri revealed a lack of differentiation between different populations inhabiting neighboring seamounts and adjacent non-seamount areas (Martin et al. 1992; Bolch et al. 1993). In contrast, other population genetic 
studies of several invertebrates have shown genetic differentiation between even closely-spaced (e.g., less than $50 \mathrm{~km}$ ) seamount populations, such as chemosynthetic mussels inhabiting seamounts near New Zealand (Smith et al. 2004b) and populations of the coral Corallium lauuense among several seamounts and islands in the Hawaiian Archipelago (Baco and Shank 2005). A study of invertebrates from the Norfolk Ridge seamounts in the Southwest Pacific revealed variable results with no genetic structure for species with planktotrophic larvae: two galatheid squat lobsters, Munida thoe and Munida zebra, two chirostylid squat lobsters, Eumunida species and the gastropod Sassia remensa, but significant structure was detected for the non-planktotrophic gastropod Nassaria probelmatica (Samadi et al. 2006). The variable results of these and other studies (Shank 2010a) suggest both high levels of genetic connectivity as well as genetic isolation of seamount populations depending on the taxa examined, molecular markers employed, and the particular seamount region studied. Differing results of genetic connectivity among seamount populations have been attributed to a consistent variety of explanations, largely the distinct differences in larval dispersal modes (e.g., Samadi et al. 2006), depth differences of available habitat, and inference of physical oceanographic circulation, including both long-distance transport driven by global circulation patterns as well as theoretical local hydrodynamics that act as barriers or agents of retention to dispersal (e.g., Smith et al. 2004b). An additional potential explanation that has yet to be investigated is the marked differences in the habitat requirements of invertebrate species in association with biological hosts.

To assess the specificity and abundance of these coral host-epifaunal invertebrate relationships on seamounts, the distribution and host specificity of 22 ophiuroid morphospecies on the Northwestern Atlantic seamounts were surveyed via high-definition video (Cho 2008). 
Markedly varying degrees of ophiuroid association with their coral hosts were identified. In particular, four ophiuroid species were identified as having distinctive habitat requirements or host-associate patterns (Cho 2008). The ophiuroid Asteroschema clavigera Verrill, 1894 displayed a high fidelity in association with two gorgonian corals Paramuricea sp. and Paragorgia sp. All observations (726 total occurrences) consistently revealed that this ophiuroid occurred with either one to two individuals with arms wrapped amongst the branches of Paramuricea sp. or one to many individuals on Paragorgia sp. The ophiuroid Ophiocreas oedipus Lyman, 1879 was associated with the coral Metallogorgia melanotrichos with only a single individual occurring on the central axial stalk of a single host coral (Mosher and Watling 2009). Ophioplinthaca abyssalis Cherbonnier \& Sibouet (1972) predominantly occurred as tens of individuals on the coral host Candidella imbricata (1285 total occurrences), but this species was also observed on other hosts and substrate. Ophioplinthaca chelys Wyville Thomson, 1878 was observed predominantly on hard seafloor habitats, lacking an association with a particular coral host.

Understanding the role of seamounts in structuring the regional biogeography and biodiversity has reached a critical level given the current threats of fisheries and mining activities that target seamount ecosystems and mineral resources (Clark et al. 2010). For example, deepsea fishing techniques such as trawling and long-line fishing have been shown to destroy benthic habitat, in particular the coral habitat upon which many invertebrates live (Probert et al. 1997; Kaiser 1998; Thrush et al. 1998; Probert 1999; Waller et al. 2007). With expanding deep-sea fisheries and the concurrent disturbance of seamount habitats, particularly those occupied by slow-growing cold-water corals, conservation efforts for these areas have increased (Clark et al. 2010). Relevant to the present study is the precautionary closure of four seamount areas in the 
North Atlantic to deep-sea fisheries activities, including 25 peaks on 13 fishable seamounts in the Corner and New England seamount chains (Waller et al. 2007; Shank 2010b).

Understanding the extent of genetic connectivity between seamounts and seamount regions provides strategic information for the creation and design of marine protected areas, conservation strategies and efforts, information similarly utilized for the conservation of shallow coral reef communities (Palumbi 2003; Richards et al. 2007).

To assess (and inform managers with insights into) the extent of genetic connectivity among North Atlantic seamounts and the hypothesis that these seamounts act either as isolating mechanisms or stepping-stones for invertebrate dispersal, we examined mt16S and mtCOI gene sequence data from populations of four ophiuroid species inhabiting the New England and Corner Rise Seamounts. In addition to examining the fundamental question of gene flow and isolation among seamounts in different regions of the North Atlantic, correlations of hostspecificity with patterns of gene flow were investigated to assess the potential effect host or habitat specificity may have on genetic structure. The varying fidelity to their coral hosts (Cho 2008; Shank 2010a) and current knowledge of species-specific reproductive modes (Tyler 1980; Hendler 1991; McEdward and Miner 2001; Mosher and Watling 2009) in the four target ophiuroid species were used to provide a priori expectations of relative connectivity based on these ecological differences. As such, we predicted that $A$. clavigera and $O$. oedipus would have similar patterns of dispersal and rates of gene flow as both are considered to be broadcast spawners and maintain highly-specific associations with coral hosts through which genetic connectivity may be influenced by similar intrinsic and extrinsic co-evolutionary forces (e.g., smaller effective population sizes and selection for specific hosts). Distinctive (or contrasting) patterns were expected between these broadcast spawning ophiuroid species and the two 
(potentially brooding) ophioplinthacid species, most notably $O$. chelys, as this ophiuroid displays no association with any faunal host.

\section{Materials and Methods}

\section{Study Region}

The seamounts of the Northwest Atlantic include three regional seamount groups, the New England Seamounts, the Corner Rise Seamounts, and Muir Seamount (Fig. 1). The New England Seamounts comprise the longest seamount chain in the North Atlantic consisting of more than 35 major peaks with elevations ranging from 400-4000 m (Shank 2010b). The seamount chain extends $1200 \mathrm{~km}$ along a northwest-southeast direction, with Bear Seamount on the continental slope south of the Georges Bank and Nashville Seamount at the end of the Bermuda Rise (Zheng and Arkani-Hamed 2002). The Corner Rise Seamounts are a cluster of seamounts between the Mid-Atlantic Ridge and the New England Seamount chain. The Corner Rise Seamounts consist of $\sim 50$ seamounts (Cairns 2007) whose western-most end is $\sim 300 \mathrm{~km}$ east of the New England Seamounts. Muir Seamount, an elongate mount located north of Bermuda, is separated by $\sim 420 \mathrm{~km}$ and $\sim 950 \mathrm{~km}$ at its closest point to the New England and Corner Rise Seamounts, respectively.

The physical oceanographic circulation in the region is dominated by the dynamics of the Gulf Stream flow and eddy system. The mean directional flow of the Gulf Stream bisects the New England Seamounts near Manning Seamount (Fig. 1) and continues northeast well above the Corner Rise Seamounts, and to at least $2000 \mathrm{~m}$ depth (Qiu 1994). This interaction is believed to form gyres to depths of $2000 \mathrm{~m}$ to $3000 \mathrm{~m}$, with circulation occurring in opposite directions 
(e.g., to the east in the north and to the west in the south) (Ezer 1994; Qiu 1994). Circulation models based on empirical current data suggest a predominant "gyre-like" circulatory pattern that encompasses almost the entirety of the Corner Rise Seamounts to depths greater than 2000 m (see Fig. 7, Qiu 1994).

\section{Sample collection}

Individuals of the four target ophiuroid species, Asteroschema clavigera Verrill, 1894, Ophiocreas oedipus Lyman, 1879, Ophioplinthaca abyssalis Cherbonnier \& Sibouet, 1972, and Ophioplinthaca chelys Wyville Thomson, 1878 were collected from 12 seamount peaks in 2005, during the 2005 Deep Atlantic Stepping Stones research expedition aboard the $R / V$ Ronald $H$. Brown using the ROV Hercules (Table 1). In 2003, specimens from Manning and Muir Seamount were collected using the DSV Alvin and the $R / V$ Atlantis. Both Alvin and Hercules utilized Kraft Predator force-reflecting manipulator arms for the collection of individual host corals and ophiuroid associates, insulated bioboxes for in-situ sample storage, and two suction vacuum samplers for additional specimen collection. The manipulator claw was modified with a custom-designed cutting blade to aid in the collection of host corals and attached ophiuroid associates. Individuals were processed immediately following the recovery of the vehicles, and initially sorted and identified on board the ship to preliminary morphospecies. Arms of individuals identified as A. clavigera and O. oedipus were subsampled and frozen for shorebased genetic analyses while the remaining whole individuals were preserved (in $4 \%$ formalin, and transferred after 24 hours to $70 \%$ ethanol). Whole individuals of $O$. abyssalis and $O$. chelys were frozen for subsequent genetic analysis. Museum voucher specimens were provided to the Yale-Peabody Museum (New Haven, CT) and the National Museum of Natural History 
(Washington, DC) for morphological confirmation of species identification. Additional ophiuroid specimens from Bear Seamount were collected on research cruise DE 02-06 in 2002 aboard the $R / V$ Delaware II and preserved in $70 \%$ ethanol. Samples from Picket Seamount were processed and frozen following collection by DSV Alvin in 2005 during research cruise AT12-1.

\section{DNA extraction, PCR, and sequencing}

Genomic ophiuroid DNA was extracted using a 5\% Chelex extraction protocol described previously (Walsh et al. 1991; Sponer and Roy 2002). A 1-3 mm piece of ophiuroid arm tissue was minced, added to $500 \mu \mathrm{l}$ of $5 \%$ Chelex solution (Bio-Rad Hercules, CA), and heated for $3 \mathrm{~h}$ at $65^{\circ} \mathrm{C}$ with the tissue completely submerged within the chelex beads. The solution was then vortexed, heated to $95^{\circ}-100^{\circ} \mathrm{C}$ for 10 minutes, and then centrifuged at $13,500 \times \mathrm{g}$ for 10 minutes. Ethanol-preserved samples were processed in the same way with the addition of an initial rinse of the tissue in deionized water. The genomic extracts were stored at $4^{\circ} \mathrm{C}$ for short-term storage (weeks) and $-20^{\circ} \mathrm{C}$ for long-term storage (months).

Both mitochondrial 16S and COI genes have been used in genetic studies of ophiuroids including the identification of cryptic species in ophiuroids (Baric and Sturmbauer 1999; Sponer et al. 2001; Roy and Sponer 2002; Sponer and Roy 2002; Hunter and Halanych 2008).

However, COI has been noted as a difficult gene to use reliably with specific ophiuroid species (Sponer et al. 2001). To identify informative population genetic markers in ophiuroids, several molecular markers were examined for their utility to detect genetic variation, including mitochondrial 16S, COI, COX2, NAD5, ATP6, nuclear ITS, and internally-developed microsatellites (Cho, unpub data). NAD5, ATP6, nuclear ITS, and the microsatellite markers were largely invariable while COX2 and ATP6 were too inconsistent in amplification for reliable 
use. Two mitochondrial DNA markers consistently amplified gene fragments from the four species of ophiuroids. Specifically, one fragment from the 16S rRNA mitochondrial gene was sequenced for all four species and one fragment from the mtCOI was sequenced for $A$. clavigera and $O$. oedipus.

A fragment of the mitochondrial 16S rRNA (16S) was amplified with the universal primers 16SarL (5'-CGCCTGTTTATCAAAAACAT-3') and 16SbrH (5'CCGGTCTGAACTCAGATCACGT-3’) (Palumbi et al. 1991). These primers performed consistently for all four species and were used for sequencing $426 \mathrm{bp}$ of the $16 \mathrm{~S}$ gene for $A$. clavigera, $466 \mathrm{bp}$ for O. oedipus, $432 \mathrm{bp}$ for O. abyssalis, and $421 \mathrm{bp}$ for O. chelys. Most fragments were amplified in $25 \mu \mathrm{l}$ PCR reactions containing 1X PCR buffer (Promega), $2.5 \mathrm{mM}$ $\mathrm{MgCL}_{2}, 1.0 \mathrm{mM}$ of each dNTP, $0.5 \mu \mathrm{M}$ of each primer, $0.5 \mathrm{M}$ Betaine, 1-2 $\mu 1$ of extracted template, and $0.2 \mathrm{U}$ of Taq polymerase (Promega). Some fragments were amplified using $1 \mathrm{X}$ PCR Buffer (Eppendorf), $2.5 \mathrm{mM} \mathrm{MgCL}_{2}, 1.0 \mathrm{mM}$ of each dNTP, $0.5 \mu \mathrm{M}$ of each primer, $1 \mathrm{X}$ TaqMaster PCR Enhancer (Eppendorf), 1-2 $\mu$ l of extracted template, and 0.2U of Taq polymerase (Eppendorf). PCR was performed under the following conditions: initial denaturation for $2 \mathrm{~min}$ at $94^{\circ} \mathrm{C}$, followed by 30 cycles of denaturation at $94^{\circ} \mathrm{C}$ for $1 \mathrm{~min}$, annealing at $45^{\circ} \mathrm{C}$ for $1 \mathrm{~min}$, and extension at $72^{\circ} \mathrm{C}$ for $45 \mathrm{sec}$, followed by a final extension phase of $72^{\circ} \mathrm{C}$ for $7 \mathrm{~min}$.

A fragment of the mitochondrial COI gene was amplified for analyses from $A$. clavigera and $O$. oedipus samples using the primers mCOIF100 for (5'-GCCGGAACTGTAGGAACAG3') and COIR1340a rev (5'-GAGTATCGTCGGGGCAT-3') developed by Dr. Paula Cisternas (pers. comm.). These primers amplified $924 \mathrm{bp}$ of mtCOI for $A$. clavigera and $1161 \mathrm{bp}$ for $O$. oedipus in $25 \mu \mathrm{l}$ PCR reactions under the same PCR conditions as described above except for 
modifications to the annealing temperature. Genomic DNA was amplified with an annealing temperature of $56^{\circ} \mathrm{C}$ for $\mathrm{A}$. clavigera and an annealing temperature of $50^{\circ} \mathrm{C}$ for $\mathrm{O}$. oedipus.

Amplicons of 16S were purified directly using either the QIAquick PCR Purification kit (Qiagen) or the SV Gel and PCR Cleanup Kit (Promega) and eluted into a final $30 \mu$ l volume. PCR products of COI were gel purified using the QIAquick Gel Extraction kit (Qiagen) and the SV Gel and PCR Cleanup Kit (Promega) and eluted into a final $30 \mu$ l volume. Purified PCR products were then used in one-eighth format sequencing reactions using Big Dye terminators (version 3, Perkin-Elmer) in 96-well plates and purified by isopropanol precipitation before sequencing on an ABI 3730XL capillary sequencer. PCR products were sequenced bidirectionally for all ophiuroids except for 3 individuals (1 A. clavigera individual from Manning Seamount, 1 O. abyssalis individual and 1 O. chelys individual from Kelvin Seamount) from which one direction was sequenced.

\section{Genetic analyses}

Mitochondrial COI and 16S sequences were edited using Sequencher 4.8 (Gene Codes Corporation Inc.) and aligned using MAFFT v6.527 (Katoh et al. 2002). Alignments were viewed by eye in MacClade 4.08 (Maddison and Maddison 2000) and COI sequences were translated to amino acids to ensure that stop codons were not present. Representative haplotypes are available in Genbank (A. clavigera 16S: HM587828-HM587849, COI: HM587850HM587877; O. oedipus 16S: HM587797-HM587799, COI: HM587878-HM587887; O. abyssalis 16S: HM587813-HM587827; O. chelys 16S: HM587800-HM587812). Intra-specific genetic diversity was evaluated by computing the number of haplotypes, the number of

polymorphic sites, haplotype diversity $(h)$, and nucleotide diversity $(\pi)$ for all populations greater 
than one individual. Pairwise $\Phi_{\mathrm{ST}}$ were computed between the seamount populations creating a genetic distance matrix in Arlequin (Excoffier et al. 2005). To examine for congruent patterns of genetic differentiation and migration, a series of analyses (below) were performed for each species and each molecular marker separately (i.e., the four $16 \mathrm{~S}$ datasets for $A$. clavigera, $O$. oedipus, O. abyssalis, and O. chelys; the two COI datasets for A. clavigera and O. oedipus; the two concatenated $16 \mathrm{~S}+\mathrm{COI}$ datasets for $A$. clavigera and $O$. oedipus).

\section{Analyses of molecular variance}

Analyses of molecular variance (AMOVA) were conducted using the eight datasets described above using Arlequin v3.11 (Excoffier et al. 2005). The pairwise $\Phi_{\mathrm{ST}}$ values were used in a series of analyses of molecular variance (AMOVA) implemented with Arlequin to test for the geographic isolation of populations and regional groups based on seamounts. The AMOVA was performed with three hierarchical levels: within each seamount, among seamounts but within regional groups, and among regional groups where the regional groups were defined as the New England Seamounts, the Corner Rise Seamounts, and Muir Seamount. In order to detect and examine genetic structure on the scale of "adjacent seamounts," a series of AMOVA were also performed with a sliding window (Plouviez et al. 2009), grouping three "adjacently"sampled seamount populations together at a time, moving from west to east. The pairwise $\Phi_{\mathrm{ST}}$ and AMOVA were each performed with 10,000 permutations using the Kimura-2-parameter model (Kimura 1980).

A series of AMOVA were performed to test for genetic structure at depth intervals over which the populations were sampled (Table 1). Samples were grouped into $50 \mathrm{~m}$ depth bins except for a single $O$. chelys individual whose sampling depth could only be resolved to a $100 \mathrm{~m}$ 
depth bin. Pairwise $\Phi_{\mathrm{ST}}$ were computed between the depth bins and used in Arlequin to test for genetic differentiation structured by depth. The AMOVA was performed with three hierarchical levels: within each $50 \mathrm{~m}$ depth bin, among depth bins but within depth intervals, and among depth intervals. In order to identify potentially broader patterns of genetic structure based on depth, the $50 \mathrm{~m}$ depth bins were grouped into $100 \mathrm{~m}, 250 \mathrm{~m}$, and $500 \mathrm{~m}$ depth intervals to systematically test for genetic differentiation at different scales within the $1300 \mathrm{~m}-2300 \mathrm{~m}$ range of the samples available. For those species and markers where significant differentiation was detected based on depth, a series of sliding window AMOVA was also performed. For the $\mathrm{COI}$ and $16 \mathrm{~S}+\mathrm{COI}$ datasets of $A$. clavigera, four $250 \mathrm{~m}$ depth intervals were examined to identify depth intervals containing genetic structure. For the $\mathrm{COI}$ and $16 \mathrm{~S}+\mathrm{COI}$ datasets of O. oedipus, three "adjacently"- sampled $100 \mathrm{~m}$ depth intervals were grouped, proceeding from shallow to deep. The pairwise $\Phi_{\mathrm{ST}}$ and AMOVA were each performed with 10,000 permutations using the Kimura-2-parameter model (Kimura 1980).

The Mantel test (Mantel 1967) of matrix comparison was used (in Arlequin) to test for isolation-by-distance, comparing the matrix of Kimura-2-parameter genetic distances between seamount populations and a matrix of direct (over water) geographical distances between seamounts. Tajima's D (Tajima 1989) test statistic for neutral selection was calculated and the goodness-of-fit test was performed within Arlequin to determine whether the mismatch distributions of the observed data fit a model of rapid population expansion for each species.

\section{Nested clade analysis}

Parsimony networks were constructed with mtDNA haplotypes from each species, and for eight datasets (A. clavigera: $16 \mathrm{~S}, \mathrm{COI}, 16 \mathrm{~S}+\mathrm{COI}$; O. oedipus: $16 \mathrm{~S}, \mathrm{COI}, 16 \mathrm{~S}+\mathrm{COI}$; $O$. 
abyssalis: 16S, O. chelys: $16 \mathrm{~S}$ ) in TCS 1.21 (Clement et al. 2000), using a 95\% connection limit between haplotypes and treating gaps as a fifth state. Network ambiguities were resolved using criteria derived from coalescent theory wherein haplotypes are more likely to be connected to other haplotypes that occur with higher frequency, are located interior of the cladogram, and are from populations that are geographically close (Crandall and Templeton 1993; Pfenninger and Posada 2002). Nested-clade analysis was then performed using ANeCA v1.2 (Automated Nested Clade Analysis) (Panchal 2006; Panchal and Beaumont 2007) which uses GeoDis 2.5 (Posada et al. 2000) and automates the inference process. Although there has been debate over the effectiveness of nested clade approaches, including the high frequency of false positives (Panchal and Beaumont 2007; Petit 2008a; Petit 2008b), when used as part of a "battery of analyses" to validate its results (Garrick et al. 2008), it can be a practical and appropriate method to identify evolutionary processes and geographical patterns in population genetic data (Templeton 1998; Templeton et al. 2000; Templeton 2004; Panchal and Beaumont 2007; Beaumont and Panchal 2008; Garrick et al. 2008; Petit 2008a; Petit 2008b; Templeton 2008). Nested clade analysis was used in such a manner in this study, as it is one of a series of analyses among which support and congruence are sought in the results. The haplotype networks were also transformed into geographic maps of haplotype distributions (Figs. 2-4).

\section{Bayesian estimation of migration rates}

Historic levels of migration between seamount regions were estimated via the software package MIGRATE version 3.0.3 using the Bayesian framework, which provides estimates for the posterior probability density of the model parameters, given the data (Beerli and Felsenstein 2001). For these analyses, seamounts were grouped by two regions, the New England 
Seamounts and the Corner Rise Seamounts for all four species (mirroring the AMOVA analyses). Based on results of the sliding AMOVA, analysis of $A$. clavigera was performed by grouping Nashville Seamount with the Corner Rise Seamounts and an additional analysis of $O$. chelys seamount populations was performed grouping into three regions, the western New England Seamounts, eastern New England Seamounts, and the Corner Rise Seamounts. Muir Seamount was excluded due to lack of COI data from this location. Estimates of population genetic parameters were obtained from a random sample of 10 individuals from each location for each marker for each species, except for $O$. oedipus which had a total of 9 samples from the Corner Rise Seamounts. Given our use of mitochondrial genes, the HKY model was used with back mutation (Won and Hey 2005; Johnson et al. 2006). Preliminary runs were conducted to establish the uniform prior distributions for the parameters $\theta($ minimum $=0.005$, maximum $=10)$ and $\mathrm{M}$ (minimum $=0$, maximum $=7500)$. One long chain was used with 1 replicate, 5,000,000 total steps sampled, with a burn-in of 50,000 and a heating scheme with start temperatures of 1.0, $1.5,3.0$, and 1000. We assessed convergence by the comparison of results from multiple runs.

\section{Results}

From 12 seamount populations, mitochondrial sequence data was obtained from a total of 91 individuals of Asteroschema clavigera, 25 individuals of Ophiocreas oedipus, 113 individuals of Ophioplinthaca abyssalis, and 68 individuals of Ophioplinthaca chelys for 16S. For mtCOI, a total of 37 sequences were obtained from A. clavigera, and 25 sequences from O. oedipus (Table 1). Overall haplotypic diversity for all populations greater than one individual for COI was higher than that for $16 \mathrm{~S}$ in A. clavigera and O. oedipus. In the $16 \mathrm{~S}$ dataset of A. clavigera, haplotype number ranged from 2-13, the number of polymorphic sites ranged from 0-14, 
haplotype diversity ranged from $0.33-1.00$ and nucleotide diversity ranged from 0-0.0024. In the COI dataset of $A$. clavigera, haplotype number ranged from 2-13, the number of polymorphic sites ranged from 4-23, haplotype diversity ranged from 0.90-1.00 and nucleotide diversity ranged from $0.0037-0.0098$. In the $16 \mathrm{~S}+\mathrm{COI}$ dataset of $A$. clavigera, haplotype number ranged from 2-13, the number of polymorphic sites ranged from 5-27, haplotype diversity ranged from 0.90-1.00 and nucleotide diversity ranged from 0.0025-0.0075. In the $16 \mathrm{~S}$ dataset of $O$. oedipus, haplotype number ranged from 1-2, the number of polymorphic sites ranged from $0-1$, haplotype diversity ranged from 0-0.50 and nucleotide diversity ranged from $0-0.0011$. In the COI dataset of O. oedipus, haplotype number ranged from 1-5, the number of polymorphic sites ranged from 0-5, haplotype diversity ranged from $0-1.00$ and nucleotide diversity ranged from $0-0.0043$. In the $16 \mathrm{~S}+\mathrm{COI}$ dataset of $O$. oedipus, haplotype number ranged from $1-4$, the number of polymorphic sites ranged from 0-5, haplotype diversity ranged from 0-1.00 and nucleotide diversity ranged from $0.00093-0.0031$. In the $16 \mathrm{~S}$ dataset of $O$. abyssalis, haplotype number ranged from 2-9, the number of polymorphic sites ranged from 2-11, haplotype diversity ranged from 0.43-0.72 and nucleotide diversity ranged from 0.0017-0.0039. In the $16 \mathrm{~S}$ dataset of $O$. chelys, haplotype number ranged from 2-7, the number of polymorphic sites ranged from 1-7, haplotype diversity ranged from $0.20-0.73$ and nucleotide diversity ranged from 0.00093-0.0026.

\section{Haplotype distribution}

The geographical distribution of the ophiuroid haplotypes in each species are presented in Figures 2, 3 and 4. 
There were a total of 16 unique haplotypes in the New England Seamount chain, many found in only a single individual (Fig. 2a). Each of the Asteroschema clavigera haplotypes from the Corner Rise Seamounts was shared by populations within the New England Seamount chain. Haplotype 2 was the dominant 16S haplotype and was distributed across both the New England and Corner Rise Seamounts. Most haplotypes of COI for A. clavigera were unique and occurred singly, except for Haplotypes 1, 6, 7, and 25. Haplotype 1 was shared across the New England and Corner Rise Seamount chains, 6 haplotypes were restricted to the Corner Rise Seamounts, and the remaining 21 haplotypes were restricted to the New England Seamounts (Fig. 2b). The 16S+COI haplotype network showed a similar pattern with 6 haplotypes restricted to the Corner Rise Seamounts and 24 haplotypes restricted to the New England Seamount chain and most haplotypes occurring only once, except for haplotypes 6 and 7 (Fig. 2c).

\section{Ophiocreas oedipus}

A single dominant 16S haplotype for Ophiocreas oedipus (Haplotype 1) observed across the New England, Corner Rise and Muir Seamounts (Fig. 3a). Haplotype 2 was observed only on Rehoboth Seamount and Haplotype 3 was observed only on East Corner Seamount. COI was more variable than $16 \mathrm{~S}$ in $O$. oedipus. One haplotype was shared across the New England, Corner Rise, and Muir Seamounts, three haplotypes were shared across the New England and Corner Rise seamounts, and three haplotypes were restricted to the New England and Corner Rise Seamounts each (Fig. 3b). A similar pattern was observed for the 16S+COI haplotype network with one haplotype shared across the three seamount regions, three haplotypes shared across the New England and Corner Rise Seamounts, and four haplotypes restricted to the New England and Corner Rise Seamounts (Fig. 3c). 
Ophioplinthaca abyssalis

Six 16S haplotypes of Ophioplinthaca abyssalis were shared across the New England and Corner Rise Seamounts while seven haplotypes were restricted to the New England Seamounts and two haplotypes were restricted to the Corner Rise Seamounts (Fig. 4a).

\section{Ophioplinthaca chelys}

Four 16S haplotypes of Ophioplinthaca chelys were distributed across the New England and Corner Rise seamounts, six haplotypes were restricted to the New England Seamounts and three haplotypes were restricted to the Corner Rise Seamounts (Fig. 4b).

\section{Analyses of molecular variance}

The AMOVA of $A$. clavigera populations revealed significant differentiation among the geographic regional groups (New England Seamount chain, Corner Rise Seamounts, and Muir Seamount) for the COI and $16 \mathrm{~S}+\mathrm{COI}$ datasets $(\mathrm{p}<0.05$, Table 2$)$. The AMOVA for $O$. chelys yielded significant differences within populations, which explained the largest amount of total variance for $16 \mathrm{~S}(92.84 \%, \mathrm{p}<0.05)$ followed by differences among populations within regional groups $(12.67 \%, \mathrm{p}<0.05)$. No significant differentiation was detected for $O$. oedipus and $O$. abyssalis (Table 2).

The series of sliding window AMOVA (of adjacent seamounts) resulted in significant differentiation within A. clavigera seamount populations when Nashville Seamount and the Corner Rise Seamounts were grouped together. For O. chelys, the sliding window series of AMOVA found significant differentiation in all possible seamount groupings. No significant 
genetic differentiation was observed in the sliding window analysis of $O$. oedipus or $O$. abyssalis.

The AMOVA structured by depth intervals, with taxa grouped into 50-meter depth bins for each species and molecular marker had a sampled depth range of $1300 \mathrm{~m}$ to $2300 \mathrm{~m}$ (Table 1). Significant genetic differentiation among $250 \mathrm{~m}$ depth intervals in both the COI and $16 \mathrm{~S}+\mathrm{COI}$ datasets for $A$. clavigera ( $\mathrm{p}<0.005$ and $\mathrm{p}<0.01$, respectively) was observed. Significant differentiation was also found among both the $100 \mathrm{~m}$ and $500 \mathrm{~m}$ depth intervals for O. oedipus in both the COI and $16 \mathrm{~S}+\mathrm{COI}$ datasets $(\mathrm{p}<0.05)$.

\section{Mantel test of isolation by distance}

The Mantel test revealed a significant correlation between genetic and geographic distances for both $A$. clavigera (16S: $\mathrm{p}<0.05 ; 16 \mathrm{~S}+\mathrm{COI}$ : $\mathrm{p}<0.005$ ) and $O$. oedipus (COI: $\mathrm{P}<0.05$; $16 \mathrm{~S}+\mathrm{COI}$ : $\mathrm{p}<0.05)$ supporting isolation by distance for these species.

\section{Tajima's D test of neutrality and mismatch distribution}

Tajima's D was found to be negative and significant in four populations of three ophiuroid species. The Rehoboth populations of both A. clavigera and O. chelys had significant negative values of Tajima's D in $16 \mathrm{~S}$ ( $\mathrm{p}<0.05$ and $\mathrm{p}<0.01$, respectively). Similarly, the East Caloosahatchee Seamount population of $O$. chelys $(\mathrm{p}<0.05)$, the Manning Seamount population of A. clavigera (16S: $\mathrm{p}<0.05$, COI: $\mathrm{p}<0.05,16 \mathrm{~S}+\mathrm{COI}$ : $\mathrm{p}<0.01$ ), and the Kelvin Seamount population of $O$. abyssalis were also significantly negative $(\mathrm{p}<0.05)$. The goodness-of-fit test of the model of rapid expansion could not be rejected for those seamount populations with negative 
Tajima's D values (data not shown). Such negative values typically signify an excess of low frequency polymorphisms, indicating population size expansion and/or positive selection.

\section{Nested clade analysis}

Parsimony network analysis of the $16 \mathrm{~S}$ datasets for $A$. clavigera, O. oedipus, and $O$. chelys resulted in star-like phylogenies with a single central haplotype, identified as the “ancestral" or "root haplotype" (Crandall and Templeton 1993; Castelloe and Templeton 1994). The root haplotype was numerically dominant in each of these cases (Fig. 5a, Fig. 6a, and Fig. 6e). The haplotype network obtained from $16 \mathrm{~S}$ sequences of $O$. abyssalis was comprised of 15 haplotypes, the two most common were centrally located within the network (Fig. 6d). This pattern is similar to the one observed for the COI and $16 \mathrm{~S}+\mathrm{COI}$ dataset of O. oedipus (Fig. 6b). The haplotype networks obtained from the COI and $16 \mathrm{~S}+\mathrm{COI}$ datasets of $A$. clavigera were highly reticulated and did not show the star-phylogeny found in the other datasets (Fig. 5b and 5c). Nested clade analysis revealed several events of contiguous range expansion, restricted gene flow with isolation by distance, and allopatric fragmentation for A. clavigera, O. oedipus, and O. abyssalis (Table 3).

\section{Bayesian estimation of migration rates}

The estimates of the parameters $\theta$ and $m / \mu$ converged when samples were grouped into seamount regions, the New England Seamounts and the Corner Rise Seamounts, for O. oedipus, O. abyssalis, and O. chelys. For A. clavigera estimates converged when Nashville Seamount was grouped with the Corner Rise Seamounts and compared to the remaining New England 
Seamounts (Table 4). Asymmetrical gene flow was strongly evident in the 16S+COI datasets of A. clavigera and $O$. oedipus and the $16 \mathrm{~S}$ datasets of $O$. abyssalis and $O$. chelys. Estimates of historical migration indicated a predominant westward movement in both A. clavigera and $O$. oedipus, suggesting migrants from the Corner Rise Seamounts (including Nashville Seamount for $A$. clavigera) being an order of magnitude greater than the historical number of migrants traveling in the reverse direction. For $O$. abyssalis and $O$. chelys, the pattern was reversed with the historical number of migrants from the New England Seamounts going to the Corner Rise Seamounts being two orders of magnitude greater than those traveling in the reverse direction (Figure 7).

\section{Discussion}

\section{Study Limitations}

This study is a multi-species approach to understanding the extent of genetic connectivity and isolation among the North Atlantic seamounts, identifying congruent and incongruent patterns of connectivity and dispersal among four ophiuroid species, of which three are intimately associated (with varying specificity) to their host coral. Before discussing the findings of this study, it is important to note that the sample sizes for several populations inhabiting different seamounts were low, and may have limited the full recovery of genetic diversity within populations. For example, the smallest samples sizes were in O. oedipus with less than six individuals for each of ten seamounts. Sufficient non-destructive sampling (i.e., discrete submersible collections rather than bottom trawling- type practices) for population genetic studies in the deep sea is commonly limited by the inaccessibility to the abundance of individuals from any given population. This restriction is particularly acute when advancing 
studies of species with small census population sizes and seafloor encounter rates (and submersible collection capacity). This limitation of sufficient or abundant samples has previously been identified as a pervasive factor that hinders the accurate estimation of endemism, population genetics, and faunal isolation on seamounts (McClain 2007; Thoma et al. 2009). Small populations are inherently those in greatest need of conservation genetic approaches (Frankham 1995) and critical to understand for the effective management of vulnerable seamount ecosystems, such as cold-water corals and their associates, from the destructive threats of fisheries activities and resource mining (Clark et al. 2010). Therefore, attempts were made to minimize the biases of small sample sizes through conservative analytical approaches and interpretations of patterns, recognizing that additional sampling of these understudied taxonomic groups, ecological relationships, and vastly underexplored New England and Corner Rise Seamounts (and adjacent regions) will allow further elucidation of the observed patterns described below.

\section{Patterns of genetic connectivity}

Several congruent patterns of connectivity and dispersal among ophiuroid species were revealed. In general, gene flow was evident for all four ophiuroid species across the three seamount regions. Similar levels of gene flow, with little to no evidence of seamount population structure, have been observed between populations of fish (e.g., Martin et al. 1992; Bolch et al. 1993), corals (e.g., Smith et al. 2004a; Thoma et al. 2009), and squat lobsters and a plankotrophic gastropod (e.g., Samadi et al. 2006). However, unlike the majority of these studies, each of the $16 \mathrm{~S}$ haplotype networks for A. clavigera, O. oedipus, and O. chelys revealed star-like phylogenies and an abundant common haplotype with many closely associated rare 
haplotypes, indicative of rapid population expansion (Slatkin and Hudson 1991; Teske et al. 2005). Expansion (and non-equilibrium dynamics) was further supported by the: 1) statistically significant negative Tajima's D values for several seamount populations of A. clavigera, $O$. abyssalis, and $O$. chelys; 2) inability of the goodness-of-fit test of mismatch distributions to reject the null hypothesis of a model of expansion for these populations (Aris-Brosou and Excoffier 1996; Tajima 1996); 3) nested clade analysis results in support of contiguous range expansion for several clades of the COI haplotype networks of A. clavigera and O. oedipus, and the $16 \mathrm{~S}$ haplotype network of $O$. abyssalis; and the 4) widespread distribution of haplotypes in each of the four ophiuroids species, where every species hosted haplotypes shared across all seamount regions.

In contrast to these congruent patterns of gene flow observed in all four ophiuroid species, several incongruent patterns emerge in the connectivity and population structure for the different species. Population structure was detected through the AMOVA based on seamount regions, which identified significant structure between Nashville and the Corner Rise Seamounts and the rest of the New England Seamounts in A. clavigera. A dissimilar pattern of genetic differentiation was detected for populations of $O$. chelys, where significant genetic structure was detected between seamounts within seamount regional groups as well as within seamount populations. This would indicate that the genetic structure within this species occurs on a smaller geographic scale in contrast to the scale of seamount regional groups observed in $A$. clavigera. In addition, several haplotypes were restricted to either the Corner Rise or New England Seamount chains with a greater abundance of unique haplotypes occurring within the New England Seamount than in the Corner Rise Seamounts. These results suggest that while genetic connectivity among regional seamount groups has occurred in the past, there are clear 
indications of genetic structure between the New England Seamount region and the Corner Rise Seamounts.

Although incongruent patterns of connectivity are apparent when each species is examined separately, there is a striking congruence among species within the same family (Asteroschematidae, A. clavigera and $O$. oedipus versus Ophiacanthidae, $O$. abyssalis and $O$. chelys). As seamounts are often distributed in linear chains and provide discrete hard substrate habitat in the abyssal plains, it has been hypothesized that seamount fauna follow a steppingstone model of dispersal, which would result in patterns of genetic isolation by distance (Wright 1931; Wright 1951; Hubbs 1959; Kimura and Weiss 1964; Rogers 1994). Nested clade analysis supports a stepping stone model of dispersal and isolation by distance for $A$. clavigera as did the Mantel test for A. clavigera and O. oedipus. Both A. clavigera and O. oedipus displayed genetic structure based on depth while $O$. abyssalis and $O$. chelys did not. In addition, both A. clavigera and O. oedipus strongly favor westward historical migration with migrants from the Corner Rise Seamounts (including Nashville Seamount for A. clavigera) being an order of magnitude greater than the number of migrants traveling in the reverse direction. In O. abyssalis and $O$. chelys, this directional migration is reversed, with strongly favored eastward historical migration (Fig. 7). Interestingly, this striking asymmetry of migration correlates with species dispersal modes and fidelity to host corals, i.e., "broadcast spawners" with high fidelity to the west vs. "brooders" with low fidelity to the east.

These congruent and incongruent patterns of gene flow and genetic structure may be due to a variety of factors previously regarded as inherently important in the connectivity of seamount populations (e.g., depth, dispersal strategies, and physical oceanographic processes; Rogers 1994; Clark et al. 2010; Shank 2010a). Indeed, the observed patterns may be best 
explained by the complex interaction of biological and physical factors, which include life history strategies, depth and environmental gradients, the temporal and spatial dynamics of hydrographic circulation, as well as the specificity of host-associate relationships.

\section{Life history and dispersal strategies}

As observed in seamount gastropod and squat lobster species (Samadi et al. 2006), potential differences in reproductive strategies may relate to the differences in observed patterns of gene flow and genetic structure. Deep-sea ophiuroids are known to have a wide-range of reproductive strategies (Tyler 1980; Hendler 1991). Reproductive studies of O. oedipus have characterized this species as a broadcast spawner with large yolky eggs (Mosher and Watling 2009). A similar larval mode of dispersal has been hypothesized in the closely related $A$.

clavigera (C. Mosher pers. comm.). Although no reproductive studies have determined empirically the reproductive strategies or mode of larval dispersal for $O$. abyssalis or $O$. chelys, studies of species from closely related species within the same family, Ophiacanthidae, found benthic, lecithotrophic larvae characterized by either brooding, viviparity, or direct development (Hendler 1991; McEdward and Miner 2001). These markedly different strategies of dispersal"broadcast spawners" vs. "brooders" in the examined ophiuroids correspond directly with the observed "incongruent" patterns of inferred dispersal and asymmetrical gene flow between the New England and Corner Rise Seamounts (Fig. 7). Detailed examination of the reproductive biology in these species would be highly informative in assessing the importance of reproductive strategy in generating the observed patterns of dispersal and genetic connectivity.

\section{Depth and environmental gradients}


It is well known that benthic community composition on seamounts can be depthstratified, often reflecting fundamental environmental gradients, such as temperature, oxygen concentration, food availability, and pressure that correlate with depth (O'Hara 2007). Most deep-sea animals have a limited bathymetric range (e.g., Rex et al. 1999), including cold-water corals that serve as available habitat. Fragmentation and restriction of biogenic habitats over depth horizons may be shared among seamounts and structure the dispersal of larvae at different depth intervals. The "biological isolation" of seamounts may result from the lack of available and suitable biogenic habitat. Evidence of depth-stratified genetic structure would point to the role of the environmental gradients and the restrictive dependency of associated invertebrates to their biological host as factors regulating genetic diversity and divergence in seamount systems.

Cluster and multivariate analyses of seamount community composition via submersible imaging surveys at the time of sample collection on these seamounts preliminarily revealed compositional changes in faunal community structure at $1300 \mathrm{~m}, 2300 \mathrm{~m}$, and $2600 \mathrm{~m}$ (Cho 2008). Similarly, distinct depth patterns for faunal assemblages have been observed on Patton seamount in the Gulf of Alaska (Hoff and Stevens 2005) and several studies have found faunal boundaries associated with depth in the North Atlantic (megabenthic fauna, Haedrich et al. 1980; asteroids, Howell et al. 2002; cerianthid anemones, Shepard et al. 1986). In addition, the maximum depths of deep-water corals often reflect changes in the depths of water masses that have temperatures suitable for the corals, as was observed for deep-water gorgonian corals in the Northeast Channel of Canada (Mortensen and Buhl-Mortensen 2004). The depth distribution of host corals likely has a marked impact on the genetic structure of associated fauna, and as such, attempts were made herein to identify such patterns. 
Two ophiuroid species displayed evidence of genetic differentiation significantly structured by depth. Analyses of molecular variance revealed significant genetic differentiation among $250 \mathrm{~m}$ depth bins of $A$. clavigera populations (relatively high sample sizes) and $100 \mathrm{~m}$ depth bins for $O$. oedipus (relatively low sample sizes). Both of these species have highly restrictive associative relationships with specific coral hosts and their distributions may be limited by the distribution of their coral hosts. As broadcast spawners, their dispersal may be limited hydrographically to specific depth ranges that effectively permit the acquisition of their specific coral host. This may explain why the data available for the two ophioplinthacids, which display less host specificity and may be 'brooders', do not suggest genetic structure by depth. In addition, $O$. oedipus has the most restricted relationship of all four ophiuroid species being an obligate symbiont of only one species of coral, while A. clavigera has two coral hosts. The combined bathymetric range of Paramuricea sp. and Paragorgia sp. (host corals of A. clavigera) may be greater than the bathymetric range of M. melanotrichos (the single host coral of $O$. oedipus) and may therefore account for the smaller scale of genetic structure based on depth for O. oedipus (100 m) versus A. clavigera $(250 \mathrm{~m})$.

These results correspond with other studies that have found genetic structure based on depth. Populations of the deep-sea amphipod Eurythenes gryllus were genetically distinct at different depths on the scale of ocean basins (France and Kocher 1996). Genetic analyses of the mitochondrial 16S gene of the deep-sea protobranch bivalve Deminucula atacellana detected genetically distinct populations above and below $2500 \mathrm{~m}$ (Chase et al. 1998) and revealed the greatest genetic divergence among populations at different depths versus geographic distance (Zardus et al. 2006). Analyses of three nuclear markers in the deep-water coral Oculina sp. revealed a singular deep-water reef as a strong genetic outlier from all other populations (Eytan 
et al. 2009) and genetic analyses of 6 microsatellites of the symbiotic dinoflagellate

Symbiodinium sp. revealed strong population differentiation between deep and shallow sites on the same reef (Kirk et al. 2009).

As previously recognized, the significant depth results may be a sampling artifact due to the low sample sizes of specific populations. However, the depth interval grouping of populations in the present analyses serves to minimize such biases brought about by small samples sizes and previous studies have shown that limited numbers of haplotypes in sequencebased population genetic studies obtain reliable species geneaologies (Hey and Kliman 1993;

Kliman and Hey 1993). In addition, the affect of different sample locations relevant to seamount morphology (i.e., peak versus slope versus base) were not expressly examined, as samples were not sufficient to resolve such issues. Nevertheless, the detection of a genetic signal as a function of depth suggests the importance of this factor and warrants further study.

\section{Physical hydrographic dynamics}

Additional physical factors such as long-distance transport driven by global circulation patterns and local theoretical hydrodynamics have been proposed as potential barriers or agents of retention to dispersal (e.g. Smith et al. 2004b). The New England and Corner Rise Seamounts have summits that range from $<1$ to $3 \mathrm{~km}$ depth, and, except for the westernmost of the New England Seamounts that arise from the continental slope, they extend to abyssal depths (40005000 meters). They lie within oceanographic settings that range from a deep western boundary current (flowing north to south) to the dynamic Gulf Stream, to abyssal quiescence. The Gulf Stream is the major western boundary current in the North Atlantic, initiating in the Caribbean with deep mean flow intersecting the New England Seamount chain near Manning Seamount 
(Richardson 1980; Hogg et al. 1986; Hogg 1992; Qiu 1994). Physical oceanographic studies of North Atlantic circulation have documented the creation of recirculating gyres from the interaction of the Gulf Stream with the New England Seamount chain at depths of 3000 m (Qiu 1994). Such dynamic gyres could serve as complex physical transport mechanisms of dispersing larvae that temporally and spatially facilitate or impede gene flow across the seamounts. If $O$. abyssalis or $O$. chelys have demersal lecithotrophic larvae, their relative potential and realized dispersal may be much lower than that of $A$. clavigera and $O$. oedipus. This may explain why populations of $O$. chelys maintained significant differentiation within seamount regions and within seamount populations, a smaller geographic scale than the regional genetic differentiation observed in A. clavigera. Similar results were observed on the Norfolk Ridge seamounts (Samadi et al. 2006).

\section{Specificity of ophiuroid associates and coral hosts}

In addition to determining the connectivity and genetic structure of seamount populations affected by fisheries activities, a goal of this study was to provide a first assessment of the potential impact that partnered relationships between host coral and the epifaunal invertebrates (from obligate to facultative to indiscriminant habitat requirements) have on the connectivity and gene flow of the associated invertebrate. The connectivity patterns evident for the four species of ophiuroids with varying degrees of association with host corals may provide insight into the influence these relationships and of the distribution of the host corals have on population genetic structure. As noted previously, O. oedipus has an obligate relationship with the coral Metallogorgia melanotrichos with only a single individual occurring on the central axial stalk of a single host coral (Mosher and Watling 2009). A. clavigera displays a high fidelity in 
association with two gorgonian corals Paramuricea sp. and Paragorgia sp. occurring with either one to two individuals on a single individual of Paramuricea sp. or one to many individuals on Paragorgia sp. O. abyssalis predominantly occurs as tens of individuals on the primnoid octocoral Candidella imbricata, but this species also utilizes other coral hosts and substrates. Based on the genetic data, as $O$. abyssalis does not maintain a similar genetic structure as $O$. chelys, it may be that $O$. abyssalis shares a similar mode of reproduction as A. clavigera and $O$. oedipus. O. chelys occurs predominantly on hard seafloor habitats, lacking an association or interaction with any particular coral as a host. As both A. clavigera and O. oedipus have strong associative relationships with coral hosts, broadcast spawning provides the greatest chance for their offspring to encounter their specific coral hosts. Alternatively, O. chelys does not have the habitat requirement of a coral host and therefore lacks the need for such a widespread dispersal strategy.

No genetic differentiation was detected for $O$. oedipus, a similar pattern that coincides over the same region with the genetic variation in Metallogorgia melanotrichos (Thoma et al. 2009), the coral host with which O. oedipus has an obligate partnership (Mosher and Watling 2009). Genetic analysis of the $m s h 1$ gene of Paramuricea sp., a coral host of $A$. clavigera, has revealed three clades across this region, one clade distributed throughout the entire region except for the easternmost Corner Rise Seamount, the second clade distributed throughout the region but absent from Muir Seamount, and the third clade restricted to the westernmost New England seamounts and the continental slope (Thoma et al. 2009). Similarly, genetic structure among the three seamount regions in this study was detected for A. clavigera. The series of sliding window AMOVA indicated that the genetic discontinuity occurred in the region of Nashville Seamount, the easternmost seamount of the New England Seamount chain, and the Corner Rise Seamounts. 
This study is unique in suggesting the potential impact of associative relationships on the genetics of associate invertebrates. Congruent patterns of large-scale gene flow and population expansion were observed among all four species of ophiuroids, while incongruent patterns of dispersal, depth, and genetic structure between the major seamount chains with asymmetrical migration were also observed and species dependent. These differences correlate well with both differences in (known and inferred) dispersal strategies and the specificity of associative relationships with coral hosts and perhaps play an important role in the connectivity and genetic structure of these and other seamount populations.

\section{Conservation and management implications}

Extensive habitat damage due to intense fishing practices in the 1970s and 1980s (Waller et al. 2007) led to the 2007 closure of 13 fishable seamounts, including 25 peaks shallower than $2000 \mathrm{~m}$ on the New England and Corner Rise Seamounts to fisheries activity involving demersal fishing gear (Shank 2010b). Continued management efforts are now under consideration as this closure will end on December 31, 2010. In promoting adaptive and effective ecosystem-based management practices to protect and conserve vulnerable marine ecosystems such as those on seamounts, it is important to consider the ecological requirements and interactions of species when trying to understand the connectivity among seamount systems. More than 270 morphospecies have been observed within the Corner Rise and New England Seamounts (Cho 2008), with a diverse array of invertebrates living with "high" levels of specificity on host coral (Shank 2010b). These include, in addition to the ophiuroid species already noted, the shrimp Bathypalaemonella serratipalma inhabiting only specific Chrysogorgia and Iridogorgia coral species, and the galatheid Uroptychus inhabiting only the antipatharian Parantipathes sp. The 
present study has identified that there may be diverse patterns of connectivity and gene flow within and between seamounts and seamount chains which should be taken into account by conservation strategies. For example, the asymmetric historical migration of high host-fidelity species to the west and low host-fidelity species to the east and the specific habitats points to the need for spatial adaptive strategies that both conserve regional sources of larvae that may exist on other seamount chains as well as specific biogenic host habitat to ensure the maintenance of biodiversity in seamount ecosystems. The ecological and evolutionary significance of hostspecific relationships on potentially isolated seamounts now presents new and fundamental questions, including the extent to which host specificity plays a role in connectivity and maintenance of the more than 1350 known species associated with cold-water coral ecosystems in the deep sea.

\section{Acknowledgements}

We are grateful for the support provided by the Office of Ocean Exploration, National Oceanic and Atmospheric Administration (NA05OAR4601054) the National Science Foundation (OCE0624627; OCE-0451983; OCE-0647612), the Deep Ocean Exploration Institute (Fellowship support to TMS), the Ocean Life Institute and Academic Programs Office of the Woods Hole Oceanographic Institution, and the Census of Marine Life field program CenSeam (a global census of marine life on seamounts) (Grant \#12301). We deeply thank the submersible pilots and crews of the $R / V$ Ron Brown/Hercules at the Institute for Exploration, and $R / V$ Atlantis/Alvin for their invaluable assistance. We also extend immense gratitude to the principal investigators of the Deep-Atlantic Stepping Stones research program: Dr. Jess Adkins (USGS), Dr. Peter Auster (Univ. of Connecticut), Dr. Scott France (Univ. of Louisiana), Dr. Lauren Mullineaux 
(WHOI), Dr. Rhian Waller (Univ. of Hawaii), and Dr. Les Watling (Univ. of Hawaii). We also thank Dr. Rhian Waller (Univ. of Hawaii) for providing samples from Picket seamount, and Dr. John Moore (Florida Atlantic University) for samples from Bear seamount. 


\section{References}

Aris-Brosou S., Excoffier L. (1996) The impact of population expansion and mutation rate heterogeneity on DNA sequence polymorphism. Molecular Biology and Evolution, 13(3), 494-504.

Baco A.R., Shank T.M. (2005) Population genetic structure of the Hawaiian precious coral Corallium lauuense (Octocorallia: Coralliidae) using microsatellites. In: A. Freiwald \& J.M. Roberts (Eds). Cold-water Corals and Ecosystems. Springer-Verlag, Berlin Heidelberg: 663-678.

Baric S., Sturmbauer C. (1999) Ecological parallelism and cryptic species in the genus Ophiothrix derived from mitochondrial DNA sequences. Molecular Phylogenetics and Evolution, 11(1), 157-162.

Batiza R. (2001) Seamounts and off-ridge volcanism. In: J.H. Steele, S.A. Thorpe \& K.K. Turekian (Eds). Encyclopedia of Ocean Sciences. Academic Press, San Diego: 26962708.

Beaumont M.A., Panchal M. (2008) On the validity of nested clade phylogeographical analysis. Molecular Ecology, 17(11), 2563-2565.

Beerli P., Felsenstein J. (2001) Maximum-likelihood estimation of a migration matrix and effective population size in n subpopulations by using a coalescent approach. Proceedings of the National Academy of Sciences, 98, 4563-4568.

Bolch C.J.S., Elliott N.G., Ward R.D. (1993) Enzyme variation in south-eastern Australian samples of the blue-eye or deepsea trevalla, Hyperoglyphe antarctica Carmichael 1818 (Teleostei: Stromateoidei). Australian Journal of Marine and Freshwater Research, 44(5), 687-697.

Cairns S.D. (2007) Studies on the western Atlantic Octocorallia (Gorgonacea: Primnoidae). Part 8: New records of Primnoidae from the New England and Corner Rise Seamounts. Proceedings of the Biological Society of Washington, 120(3), 243-263.

Castelloe J., Templeton A.R. (1994) Root probabilities for intraspecific gene trees under neutral coalescent theory. Molecular Phylogenetics and Evolution, 3, 102-113.

Chase M., Etter R., Rex M., Quattro J. (1998) Bathymetric patterns of genetic variation in a deep-sea protobranch bivalve, Deminucula atacellana. Marine Biology, 131(2), 301-308.

Cho W. (2008) Faunal biogeography, community structure, and genetic connectivity of North Atlantic Seamounts. Biological Oceanography. Massachusetts Institute of Technology/Woods Hole Oceanographic Institution Joint Program, Cambridge, MA: 177.

Clark M.R., Rowden R.T., Schlacher T., Williams A., Consalvey M., Stocks K.I., Rogers A.D., O'Hara T.D., White M., Shank T.M., Hall-Spencer J.M. (2010) The ecology of seamounts: structure, function, and human impacts. Annual Review of Marine Science, 2, 253-278.

Clement M., Posada D., Crandall K.A. (2000) TCS: a computer program to estimate gene genealogies. Molecular Ecology, 9(10), 1657-1660.

Crandall K.A., Templeton A.R. (1993) Empirical tests of some predictions from coalescent theory with applications to intraspecific phylogeny reconstruction. Genetics, 134, 959969.

Epp D., Smoot N.C. (1989) Distribution of seamounts in the North Atlantic. Nature, 337, 254257. 
Etnoyer P., Woods J., Shirley T.C. (2010) How large is the Seamount Biome? Oceanography, 23, 206-209.

Excoffier L., Laval G., Schneider S. (2005) Arlequin ver. 3.0: An integrated software package for population genetics data analysis. Evolutionary Bioinformatics Online, 1, 47-50.

Eytan R.I., Hayes M., Arbour-Reily P., Miller M., Hellberg M.E. (2009) Nuclear sequences reveal mid-range isolation of an imperilled deep-water coral population. Molecular Ecology, 18(11), 2375-2389.

Ezer T. (1994) On the interaction between the Gulf Stream and the New England Seamount Chain. Journal of Physical Oceanography, 24(1), 191-204.

France S.C., Kocher T.D. (1996) Geographic and bathymetric patterns of mitochondrial 16S rRNA sequence divergence among deep-sea amphipods, Eurythenes gryllus. Marine Biology, 126(4), 633-643.

Frankham R. (1995) Conservation genetics. Annual Review of Genetics, 29, 305-327.

Fryer P., Fryer G.J. (1987) Origins of nonvolcanic seamounts in a forearc an environment. In: B. Keating, P. Fryer, R. Batiza \& G.W. Boehlert (Eds). Seamounts, Islands, and Atolls. American Geophysical Union, Wasington, DC: 61-69.

Garrick R.C., Dyer R.J., Beheregaray L.B., Sunnucks P. (2008) Babies and bathwater: a comment on the premature obituary for nested clade phylogeographical analysis. Molecular Ecology, 17(6), 1401-1403.

Haedrich R.L., Rowe G.T., Polloni P.T. (1980) The megabenthic fauna in the deep sea south of New England, USA. Marine Biology, 57, 165-179.

Hamilton E.L. (1956). Sunken islands of the Mid-Pacific Mountains. Geological Society of America Memoir 64, New York: 97 pp.

Hendler G. (1991) Echinodermata: Ophiuroidea. In: A.C. Giese, J.S. Pearse \& V.B. Pearse (Eds). Reproduction of Marine Invertebrates. Boxwood Press, Pacific Grove, CA: 355-511.

Hey J., Kliman R.M. (1993) Population genetics and phylogenetics of DNA sequence variation at multiple loci within the Drosophila melanogaster species complex. Molecular Biology and Evolution, 10(4), 804-822.

Hoff G.R., Stevens B. (2005) Faunal Assemblage Structure on the Patton Seamount (Gulf of Alaska, USA). Alaska Fishery Research Bulletin, 11(1), 27-36.

Hogg N.G. (1992) On the transport of the Gulf Stream between Cape Hatteras and the Grand Banks Deep Sea Research, 39(7/8), 1231-1246.

Hogg N.G., Pickart R.S., Hendry R.M., Smethie W.J., Jr. (1986) The Northern Recirculation Gyre of the Gulf Stream. Deep-Sea Research, 33(9A), 1139-1165.

Howell K.L., Billett D.S.M., Tyler P.A. (2002) Depth-related distribution and abundance of seastars (Echinodermata : Asteroidea) in the Porcupine Seabight and Porcupine Abyssal Plain, NE Atlantic. Deep-Sea Research I, 49, 1901-1920.

Hubbs C.L. (1959) Initial discoveries of fish faunas on seamounts and offshore banks in the Eastern Pacific. Pacific Science, 13, 311-316.

Hunter R., Halanych K. (2008) Evaluating connectivity in the brooding brittle star Astrotoma agassizii across the Drake Passage in the Southern Ocean. Journal of Heredity, 99(2), 137-148.

Johnson S., Young C., Jones W., Waren A., Vrijenhoek R. (2006) Migration, isolation, and speciation of hydrothermal vent limpets (Gastropoda ; Lepetodrilidae) across the Blanco Transform Fault. Biological Bulletin, 210(2), 140-157. 
Kaiser M.J. (1998) Significance of bottom-fishing disturbance. Conservation Biology, 12(6), $1230-1235$.

Katoh K., Misawa K., Kuma K., Miyata T. (2002) MAFFT: a novel method for rapid multiple sequence alignment based on fast Fourier transform. Nucleic Acids Research, 30(14), 3059-66.

Kimura M. (1980) A simple method for estimating evolutionary rates of base substitutions through comparative studies of nucleotide sequences. Journal of Molecular Evolution, 16, 111-120.

Kimura M., Weiss G.H. (1964) The stepping-stone model of genetic structure and the decrease of genetic correlation with distance. Genetics, 49, 561-576.

Kirk N.L., Andras J.P., Harvell C.D., Santos S.R., Coffroth M.A. (2009) Population structure of Symbiodinium sp. associated with the common sea fan, Gorgonia ventalina, in the Florida Keys across distance, depth, and time. Marine Biology, 156(8), 1609-1623.

Kliman R.M., Hey J. (1993) DNA sequence variation at the period locus within and among species of the Drosophila melanogaster complex Genetics, 133, 375-387.

Koslow J.A., Gowlett-Holmes K., Lowry J. K., O'Hara, T., Poore, G. C. B., William A. (2001) Seamount benthic macrofauna off southern Tasmania: community structure and impacts of trawling. Marine Ecology Progress Series, 213, 111-125.

Maddison W.P., Maddison D.R. (2000) MacClade. Sinauer Associates, Sunderland, MA.

Mantel N. (1967) The detection of disease clustering and a generalised regression approach. Cancer Research, 27, 209-220.

Martin A.P., Humphreys R., Palumbi S.R. (1992) Population genetic structure of the armorhead, Pseudopentaceros wheeleri, in the North Pacific Ocean: Application of the polymerase chain reaction to fisheries problems. Canadian Journal of Fisheries and Aquatic Sciences, 49(11), 2386-2391.

McClain C.R. (2007) Seamounts: identity crisis or split personality? Journal of Biogeography, 34(12), 2001-2008.

McClain C.R., Lundsten L., Ream M., Barry J., De Vogelaere A. (2009) Endemicity, biogeography, composition and community structure on a Northeast Pacific seamount. PLoS ONE, 4(1), e4141.

McEdward L.R., Miner B.G. (2001) Larval and life-cycle patterns in echinoderms. Canadian Journal of Zoology, 79(7), 1125-1170.

Mortensen P.B., Buhl-Mortensen L. (2004) Distribution of deep-water gorgonian corals in relation to benthic habitat features in the Northeast Channel (Atlantic Canada). Marine Biology, 144, 1223-1238.

Mosher C., Watling L. (2009) Partners for life: a brittle star and its octocoral host. Marine Ecology Progress Series, 397, 81-88.

O'Hara T.D. (2007) Seamounts: centres of endemism or species richness for ophiuroids? Global Ecology and Biogeography, 16, 720-732.

Palumbi S.R. (2003) Population genetics, demographic connectivity, and the design of marine reserves. Ecological Applications, 13(sp1), 146-158.

Palumbi S.R., Martin A., Romano S., McMillan W.O., Stice L., Grabowski G. (1991) The simple fool's guide to PCR, 2nd Ed. Dept. Zoology, University of Hawaii, Honolulu, HI.

Panchal M. (2006) The automation of nested clade phylogeographic analysis. Bioinformatics, 23(4), 509-510. 
Panchal M., Beaumont M.A. (2007) The automation and evaluation of nested clade phylogeographic analysis. Evolution, 61(6), 1466-1480.

Parin N.V., Mironov A.N., Nesis K.N. (1997) Biology of the Nazca and Sala y Gomez submarine ridges, an outpost of the Indo-West Pacific fauna in the Eastern Pacific Ocean: Composition and distribution of the fauna, its communities and history. Advances in Marine Biology, 32, 145-242.

Petit R.J. (2008a) On the falsifiability of the nested clade phylogeographic analysis method. Molecular Ecology, 17(6), 1404.

Petit R.J. (2008b) The coup de grace for the nested clade phylogeographic analysis? Molecular Ecology, 17(2), 516-518.

Pfenninger M., Posada D. (2002) Phylogeographic history of the land snail Candidula unifasciata (Helicellinae, Stylommatophora): Fragmentation, corridor migration, and secondary contact. Evolution, 56(9), 1776-1788.

Plouviez S., Shank T.M., Faure B., Daguin-Thiebaut C., Viard F., Lallier F.H., Jollivet D. (2009) Comparative phylogeography among hydrothermal vent species along the East Pacific Rise reveals vicariant processes and population expansion in the South. Molecular Ecology, 18, 3903-3917.

Posada D., Crandall K.A., Templeton A.R. (2000) GeoDis: A program for the cladistic nested analysis of the geographical distribution of genetic haplotypes. Molecular Ecology, 9, 487-488.

Probert P.K. (1999) Seamounts, sanctuaries, and sustainability: moving towards deep-sea conservation. Aquatic Conservation: Marine and Freshwater Ecosystems, 9, 601-605.

Probert P.K., McKnight D.G., Grove S.L. (1997) Benthic invertebrate bycatch from a deep-water trawl fishery, Chatham Rise, New Zealand. Aquatic Conservation: Marine and Freshwater Ecosystems, 7, 27-40.

Qiu B. (1994) Determining the mean Gulf Stream and its recirculations through combining hydrographic and altimetric data. Journal of Geophysical Research, 99, 951-962.

Rex M.A., Etter R.J., Clain A.J. (1999) Bathymetric patterns of body size in deep-sea gastropods. Evolution, 53, 1298-1301.

Richards V.P., Thomas J.D., Stanhope M.J., Shivji M.S. (2007) Genetic connectivity in the Florida reef system: comparative phylogeography of commensal invertebrates with contrasting reproductive strategies. Molecular Ecology, 16(1), 139-57.

Richardson P.L. (1980) Anticyclonic eddies generated near Corner Rise seamounts. Journal of Marine Research, 38, 673-686.

Richer de Forges B., Koslow J.A., Poore G.C.B. (2000) Diversity and endemism of the benthic seamount fauna in the southwest Pacific. Nature, 405(6789), 944-947.

Rogers A.D. (1994) The biology of seamounts. Advances in Marine Biology, 30, 305-350.

Rogers A.D. (2004) The biology, ecology, and vulnerability of seamount communities. International Union for Conservation of Nature \& Natural Resources.

Roy M.S., Sponer R. (2002) Evidence of a human-mediated invasion of the tropical western Atlantic by "the world's most common brittle star". Proceedings of the Royal Society of London. B, 269, 1017-1023.

Samadi S., Bottan L., Macpherson E., Richer de Forges B., Boisselier M. (2006) Seamount endemism questioned by the geographic distribution and population genetic structure of marine invertebrates. Marine Biology, 149, 1463-1475. 
Shank T.M. (2010a) Seamounts: deep-ocean laboratories of faunal connectivity, evolution, and endemism. Oceanography, 23, 108-122.

Shank T.M. (2010b) New England and Corner Rise Seamounts. Oceanography, 23, 104-105.

Shepard A.N., Theroux R.B., Cooper R.A., Uzmann J.R. (1986) Ecology of Ceriantharia (Coelenterata, Anthozoa) of the northwestern Atlantic from Cape Hatteras to Nova Scotia. Fishery Bulletin, 84, 625-646.

Slatkin M., Hudson R.R. (1991) Pairwise comparisons of mitochondrial DNA sequences in stable and exponentially growing populations. Genetics, 129, 555-562.

Smith P., McVeagh S., Mingoia J.T., France S.C. (2004a) Mitochondrial DNA sequence variation in deep-sea bamboo coral (Keratoisidinae) species in the southwest and northwest Pacific Ocean. Marine Biology, 144, 253-261.

Smith P., McVeagh S., Won Y., Vrijenhoek R. (2004b) Genetic heterogeneity among New Zealand species of hydrothermal vent mussels (Mytilidae : Bathymodiolus). Marine Biology, 144(3), 537-545.

Sponer R., Deheyn D., Roy M.S. (2001) Large genetic distances within a population of Amphipholis squamata (Echinodermata; Ophiuroidea) do not support colour varieties as sibling species. Marine Ecology Progress Series, 219, 169-175.

Sponer R., Roy M.S. (2002) Phylogeographic analysis of the brooding brittle star Amphipholis squamata (echinodermata) along the coast of New Zealand reveals high cryptic genetic variation and cryptic dispersal potential. Evolution, 56(10), 1954-1967.

Staudigal A.N., Koppers A., Lavelle J.W., Pitcher T., Shank T.M. (2010) Seamount Sciences: Quo Vadis. Oceanography, 23, 212.

Tajima F. (1989) Statistical method for testing the neutral mutation hypothesis by DNA polymorphism. Genetics, 125, 585-593.

Tajima F. (1996) The amount of DNA polymorphism maintained in a finite population when the neutral mutation rate varies among sites. Genetics, 143(3), 1457-1465.

Templeton A.R. (1998) Nested clade analyses of phylogeographic data: testing hypotheses about gene flow and population history. Molecular Ecology, 7(4), 381-397.

Templeton A.R. (2004) Statistical phylogeography: methods of evaluating and minimizing inference errors. Molecular Ecology, 13, 789-809.

Templeton A.R. (2008) Nested clade analysis: an extensively validated method for strong phylogeographic inference. Molecular Ecology, 17(8), 1877-1880.

Templeton A.R., Maskas S.D., Cruzan M.B. (2000) Gene trees: A powerful tool for exploring the evolutionary biology of species and speciation. Plant Species Biology, 15, 211-222.

Teske P.R., Hamilton H., Palsboll P.J., Choo C.K., Gabr H., Lourie S.A., Santos M., Sreepada A., Cherry M.I., Matthee C.A. (2005) Molecular evidence for long-distance colonization in an Indo-Pacific seahorse lineage. Marine Ecology Progress Series, 286, 249-260.

Thoma J.N., Pante E., Brugler M.R., France S.C. (2009) Deep-sea octocorals and antipatharians show no evidence of seamount-scale endemism in the NW Atlantic. Marine Ecology Progress Series, 397, 25-35.

Thrush S.F., Hewitt J.E., Cummings V.J., Dayton P.K., Cryer M., Turner S.J., Funnell G.A., Budd R.G., Milburn C.J., Wilkinson M.R. (1998) Disturbance of the Marine Benthic Habitat by Commercial Fishing: Impacts at the Scale of the Fishery. Ecological Adaptations, 8(3), 866-879.

Tyler P.A. (1980) Deep-Sea Ophiuroids. Oceanography and Marine Biology: An Annual Review, 18, 125-153. 
Waller R.G., Watling L., Auster P., Shank T.M. (2007) Fishing Impacts on the Corner Rise Seamounts. Journal of the Marine Biological Association of the United Kingdom, 87, 1075-1076.

Walsh P.S., Metzger D.A., Higuchi R. (1991) Chelex 100 as a medium for simple extraction of DNA and PCR-based typing from forensic material. BioTechniques, 10, 506-513.

Wessel P., Sandwell D.T., Kim S.-S. (2010) The global seamount census. Oceanography, 23, 2433.

Wilson R.R., Jr., Kaufmann R.S. (1987) Seamount biota and biogeography. In: B.H. Keating, P. Fryer, R. Batiza \& G.W. Boehlert (Eds). Seamounts, Islands, and Atolls. American Geophysical Union, Washington, DC: 355-377.

Won Y.-J., Hey J. (2005) Divergence population genetics of chimpanzees. Molecular Biology and Evolution, 22(2), 297-307.

Wright S. (1931) Evolution in Mendelian Populations. Genetics, 16, 97-159.

Wright S. (1951) The genetical structure of populations. Annals of Eugenics, 15, 323-354.

Zardus J., Etter R., Chase M., Rex M., Boyle E. (2006) Bathymetric and geographic population structure in the pan-Atlantic deep-sea bivalve Deminucula atacellana (Schenck, 1939). Molecular Ecology, 15(3), 639-651.

Zheng Y., Arkani-Hamed J. (2002) Rigidity of the Atlantic oceanic lithosphere beneath New England Seamounts. Tectonophysics, 359, 359-369. 
Table 1. Summary of the gene region and number of individuals examined by seamount and geographic regions, in this study. The depth distribution (in $50 \mathrm{~m}$ depth bins) of these individuals is provided for each species and gene region dataset.

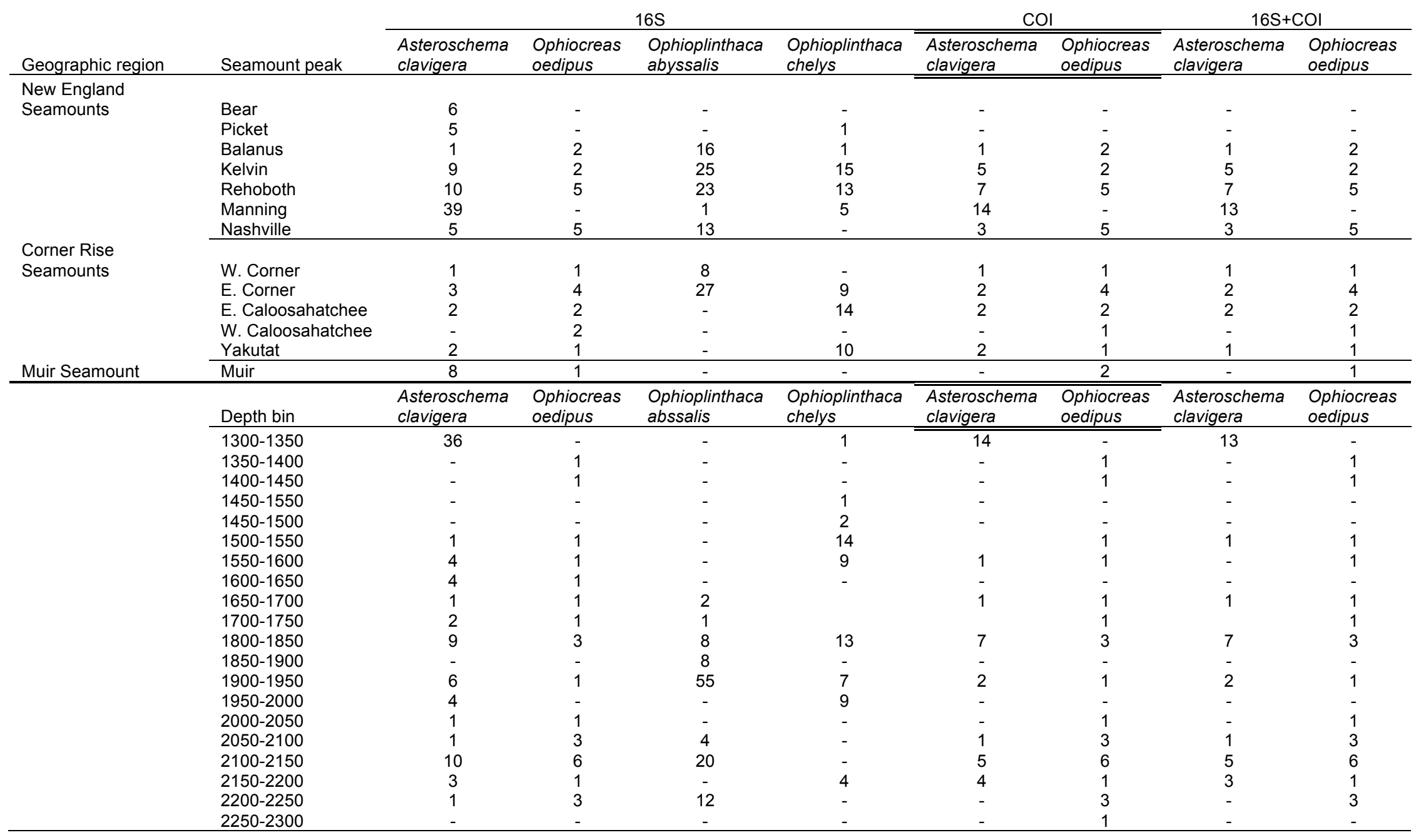


Table 2. Hierarchical AMOVA results of $16 \mathrm{~S}$, COI, and $16 \mathrm{~S}+\mathrm{COI}$ for the four ophiuroid species. Significant values of $\mathrm{P}<0.05$ are in bold.

\begin{tabular}{|c|c|c|c|c|c|c|c|}
\hline Species & Gene region & Source of variation & d.f. & SS & $\begin{array}{l}\text { Variance } \\
\text { Components }\end{array}$ & $\begin{array}{l}\% \\
\text { variation }\end{array}$ & $P$ value \\
\hline \multirow[t]{9}{*}{ A. clavigera } & \multirow[t]{3}{*}{$16 S$} & Among Regional groups & 2 & 0.964 & 0.01045 & 2.97 & $0.09109+/-0.00258$ \\
\hline & & $\begin{array}{l}\text { Among populations withın } \\
\text { regional groups }\end{array}$ & 9 & 3.034 & -0.00079 & -0.22 & $0.43287+/-0.00505$ \\
\hline & & Within populations & 79 & 27.022 & 0.34205 & 97.25 & $0.37901+/-0.00471$ \\
\hline & \multirow[t]{3}{*}{$\mathrm{COI}$} & $\begin{array}{l}\text { Among Regional groups } \\
\text { Among populations within }\end{array}$ & 1 & 4.278 & 0.16105 & 6.8 & $0.02485+/-0.00157$ \\
\hline & & regional groups & 7 & 17.457 & 0.10699 & 4.52 & $0.34822+/-0.00474$ \\
\hline & & Within populations & 28 & 58.781 & 2.09931 & 88.68 & $0.05218+/-0.00249$ \\
\hline & \multirow[t]{3}{*}{$16 \mathrm{~S}+\mathrm{COI}$} & $\begin{array}{l}\text { Among Regional groups } \\
\text { Among populations within }\end{array}$ & 1 & 4.658 & 0.19376 & 7.05 & $0.01426+/-0.00128$ \\
\hline & & regional groups & 7 & 19.543 & 0.09372 & 3.45 & $0.45109+/-0.00522$ \\
\hline & & Within populations & 26 & 63.931 & 2.45887 & 89.5 & $0.11079+/-0.00342$ \\
\hline \multirow[t]{9}{*}{ O. oedipus } & \multirow[t]{3}{*}{$16 S$} & $\begin{array}{l}\text { Among Regional groups } \\
\text { Among populations within }\end{array}$ & 2 & 0.092 & -0.00025 & -0.32 & $0.79842+/-0.00372$ \\
\hline & & regional groups & 7 & 0.279 & -0.2582 & -33.34 & $1.00000+/-0.00000$ \\
\hline & & Within populations & 15 & 1.553 & 0.10353 & 133.65 & $0.84545+/-0.00360$ \\
\hline & \multirow[t]{3}{*}{$\mathrm{COI}$} & $\begin{array}{l}\text { Among Regional groups } \\
\text { Among populations within }\end{array}$ & 2 & 1.531 & -0.00088 & -0.12 & $0.36693+/-0.00502$ \\
\hline & & regional groups & 7 & 5.358 & 0.01886 & 2.55 & $0.71515+/-0.00387$ \\
\hline & & Within populations & 15 & 10.823 & 0.72155 & 97.57 & $0.40663+/-0.00480$ \\
\hline & \multirow[t]{3}{*}{$16 S+C O I$} & $\begin{array}{l}\text { Among Regional groups } \\
\text { Among populations within }\end{array}$ & 2 & 1.116 & -0.04058 & -5.02 & $0.80653+/-0.00418$ \\
\hline & & regional groups & 7 & 5.624 & -0.03441 & -4.26 & $0.83475+/-0.00425$ \\
\hline & & Within populations & 14 & 12.369 & 0.88353 & 109.27 & $0.71950+/-0.00476$ \\
\hline \multirow[t]{3}{*}{ O. abyssalis } & \multirow[t]{3}{*}{$16 S$} & $\begin{array}{l}\text { Among Regional groups } \\
\text { Among populations within }\end{array}$ & 1 & 0.572 & -0.00085 & -0.13 & $0.62208+/-0.00528$ \\
\hline & & regional groups & 5 & 3.135 & -0.00182 & -0.28 & $0.40584+/-0.00499$ \\
\hline & & Within populations & 106 & 69.157 & 0.65242 & 100.41 & $0.46020+/-0.00480$ \\
\hline \multirow[t]{3}{*}{ O. chelys } & \multirow[t]{3}{*}{$16 S$} & $\begin{array}{l}\text { Among Regional groups } \\
\text { Among populations within }\end{array}$ & 1 & 0.171 & -0.0175 & -5.51 & $0.87822+/-0.00341$ \\
\hline & & regional groups & 6 & 3.539 & 0.0421 & 12.67 & $0.04832+/-0.00183$ \\
\hline & & Within populations & 59 & 17.386 & 0.29468 & 92.84 & $0.03158+/-0.00194$ \\
\hline
\end{tabular}


Table 3. Nested clade analysis results from three species of ophiuroids displaying regionally-significant genetic patterns.

\begin{tabular}{lllll}
\hline Species & Gene Region & Clade & Chain of inference & Demographic event inferred \\
\hline A. clavigera & $16 \mathrm{~S}$ & Total Cladogram & $1-2-3-4$ no & $\begin{array}{l}\text { Restricted gene flow with isolation by } \\
\text { distance (restricted dispersal by distance in } \\
\text { non-sexual species) }\end{array}$ \\
\cline { 2 - 5 } & COI & $2-3$ & & $\begin{array}{l}\text { Contiguous range expansion } \\
\text { Contiguous range expansion }\end{array}$ \\
& 16S+COI & Total Cladogram & $1-2-1-1-4$ no & $\begin{array}{l}\text { Restricted gene flow with isolation by } \\
\text { distance (restricted dispersal by distance in } \\
\end{array}$ \\
\cline { 2 - 5 } & & & non-sexual species) \\
\hline O. oedipus & $\mathrm{COI}$ & $2-1$ & $1-2-11-12$ no & Contiguous range expansion \\
\cline { 2 - 5 } & $16 \mathrm{~S}+\mathrm{COI}$ & Total Cladogram & $1-19$ no & Allopatric fragmentation \\
\hline O. abyssalis & $16 \mathrm{~S}$ & $2-1$ & $1-2-11-12$ no & Contiguous range expansion \\
\hline
\end{tabular}


Table 4. Estimated rates of gene flow as migrants per generation, $M=\theta m / \mu$ for the $16 \mathrm{~S}+\mathrm{COI}$ datasets of $A$. clavigera and $O$. oedipus and the $16 \mathrm{~S}$ datasets of $O$. abyssalis and $O$. chelys. NESC $=$ New England Seamount Chain; $\mathrm{CR}=$ Corner Rise.

\begin{tabular}{|c|c|c|c|c|}
\hline Species & Gene & Comparison & Number of migrants/generation & Directional bias \\
\hline \multirow[t]{2}{*}{ A. clavigera } & $16 \mathrm{~S}+\mathrm{COI}$ & NESC into CR+Nashville Seamount & 160.78 & West \\
\hline & & CR+Nashville Seamount into NESC & 1376.8 & \\
\hline \multirow[t]{2}{*}{ O. oedipus } & $16 \mathrm{~S}+\mathrm{COI}$ & NESC into CR & 117.7 & West \\
\hline & & CR into NESC & 1644.1 & \\
\hline \multirow[t]{2}{*}{ O. abyssalis } & $16 \mathrm{~S}$ & NESC into CR & 2351.2 & East \\
\hline & & CR into NESC & 84.8 & \\
\hline \multirow[t]{2}{*}{ O. chelys } & $16 \mathrm{~S}$ & NESC into CR & 24878.7 & East \\
\hline & & CR into NESC & 98.9 & \\
\hline
\end{tabular}




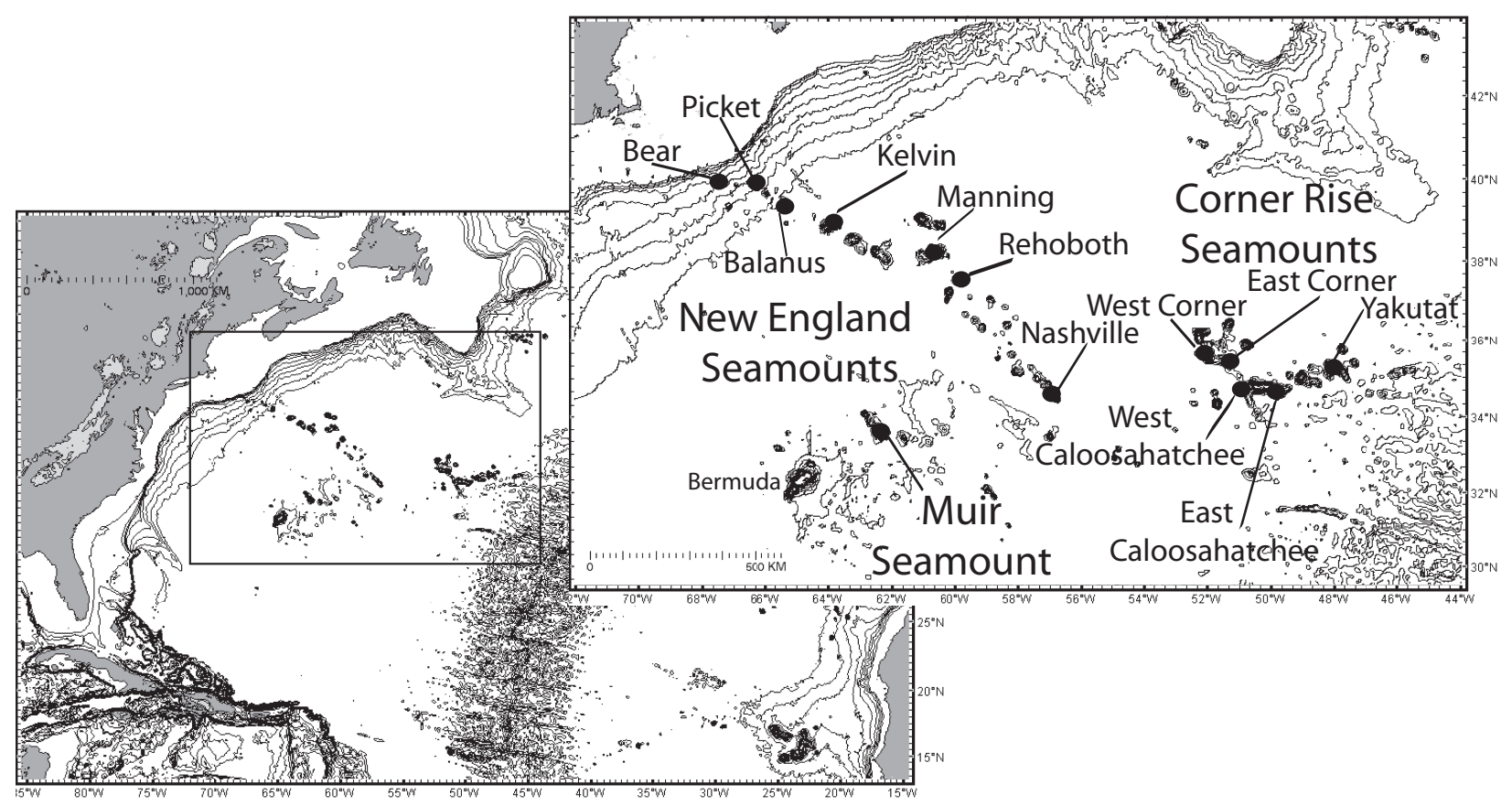

Figure 1. Regional map of the North Atlantic with inset indicating the seamounts of the New England Seamount chain, the Corner Rise Seamounts, and Muir Seamount from which samples were obtained for this study. 
a.

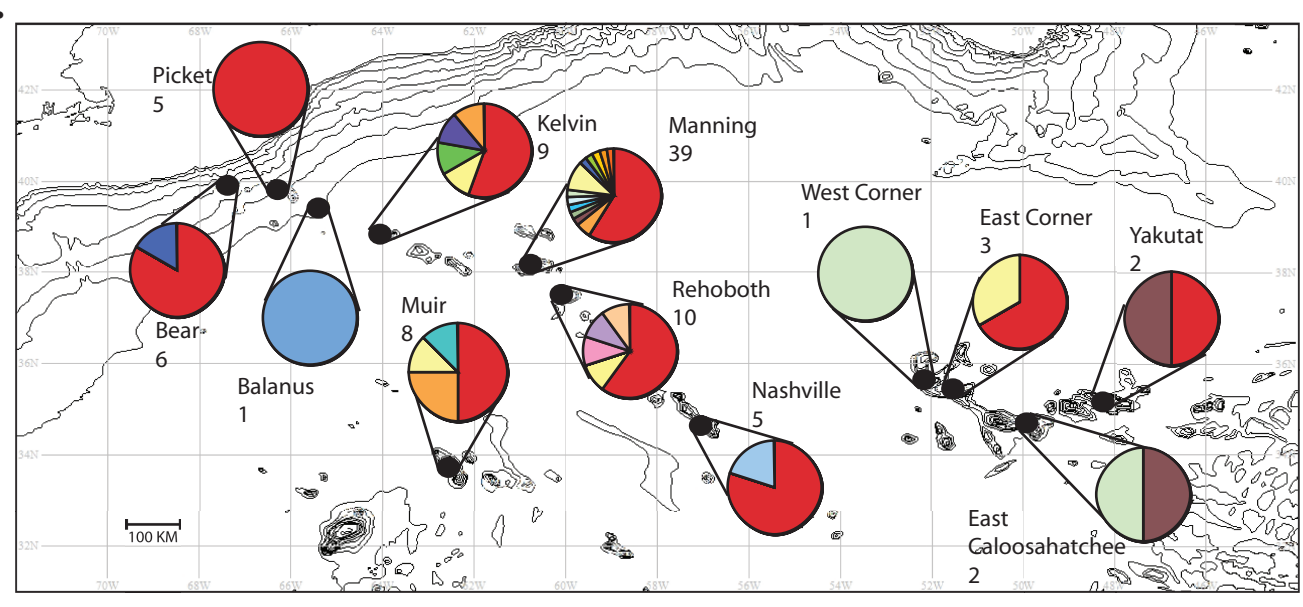

Cho and Shank Figure 2

$\square$ Haplotype 1

- Haplotype 2

口Haplotype 3

$\square$ Haplotype 4

Haplotype 5

Haplotype 6

-Haplotype 7

- Haplotype 8

口Haplotype 9

口Haplotype 10

口Haplotype 11

पHaplotype 12

口Haplotype 13

口Haplotype 14

口Haplotype 15

口Haplotype 16

- Haplotype 17

口Haplotype 18

口Haplotype 19

-Haplotype 20

-Haplotype 21

口Haplotype 22

b.
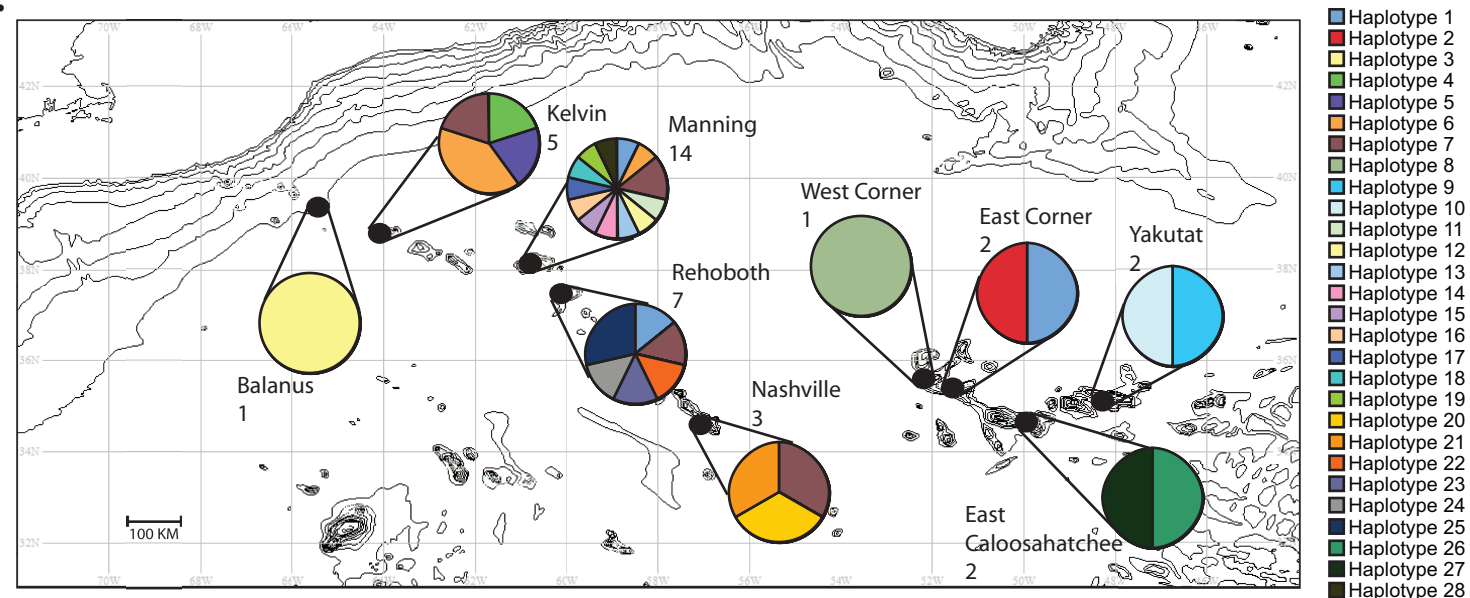

c.

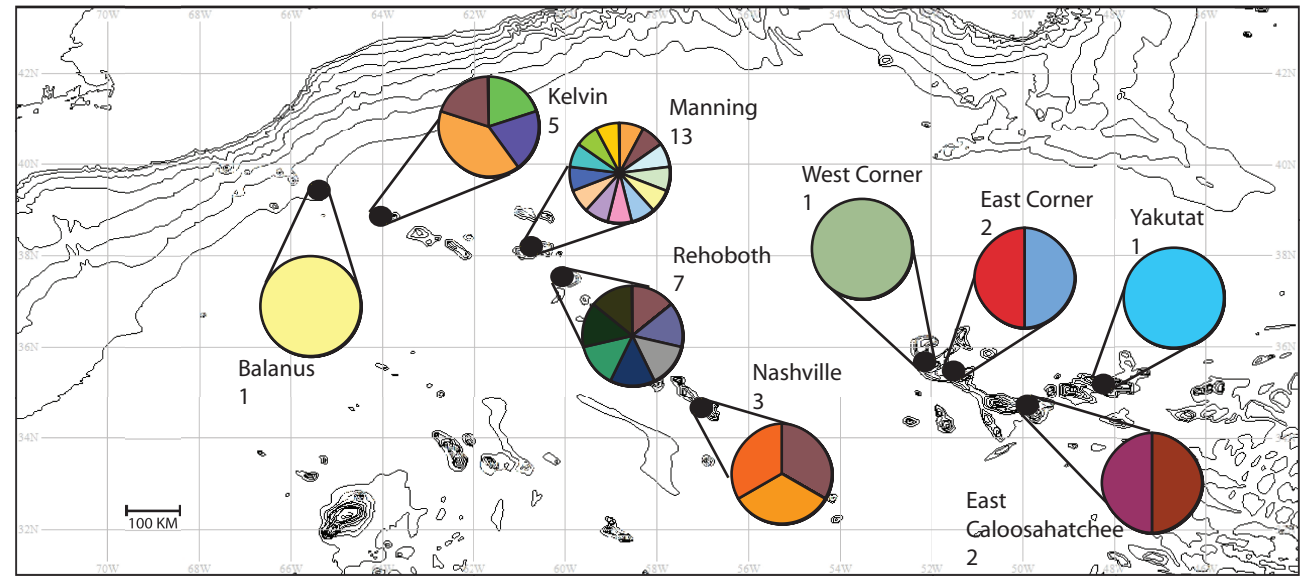

$\square$ Haplotype 1

Haplotype 2

Gaplotype 3

$\square$ Haplotype 4

口Haplotype 6

Haplotype 7

CHaplotype 8

Haplotype 10

Dhaplotype 11

Haplotype 12

Gaplotype 13

Haplotype 14

Haplotype 15

Gaplotype 16

Haplotype 17

Gaplotype 18

Haplotype 19

-Haplotype 20

Haplotype 21

Haplotype 22

Haplotype 23

Haplotype 24

Haplotype 25

Haplotype 26
Haplotype 27

Haplotype 27

Haplotype 29

Haplotype 30

Figure 2. Haplotype map for $A$. clavigera a. $16 \mathrm{~S}$ sequences, b. COI sequences, and c. $16 \mathrm{~S}+\mathrm{COI}$ sequences. Pie graphs indicate haplotypic composition of each location and numbers indicate total number of samples from each location. 
a.

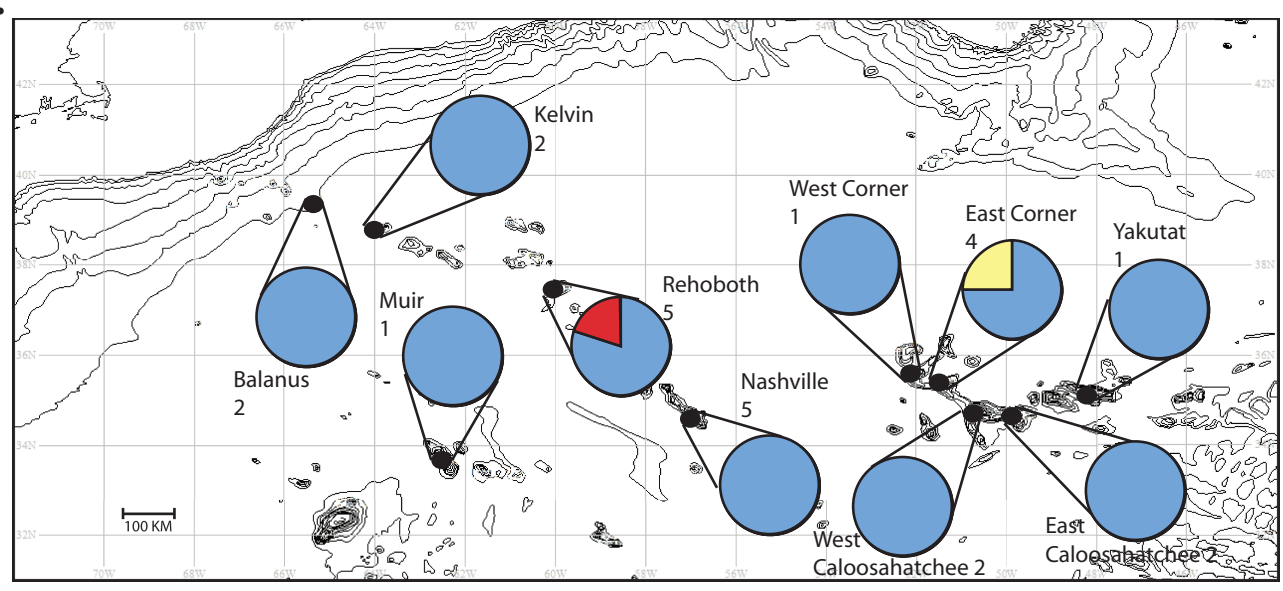

b.

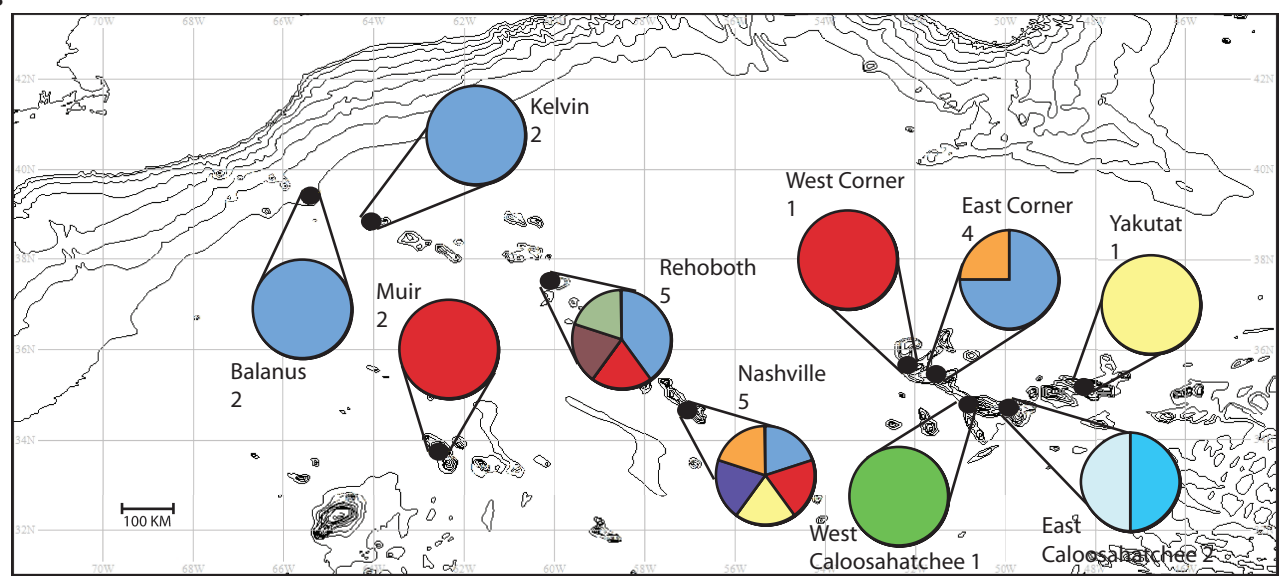

c.

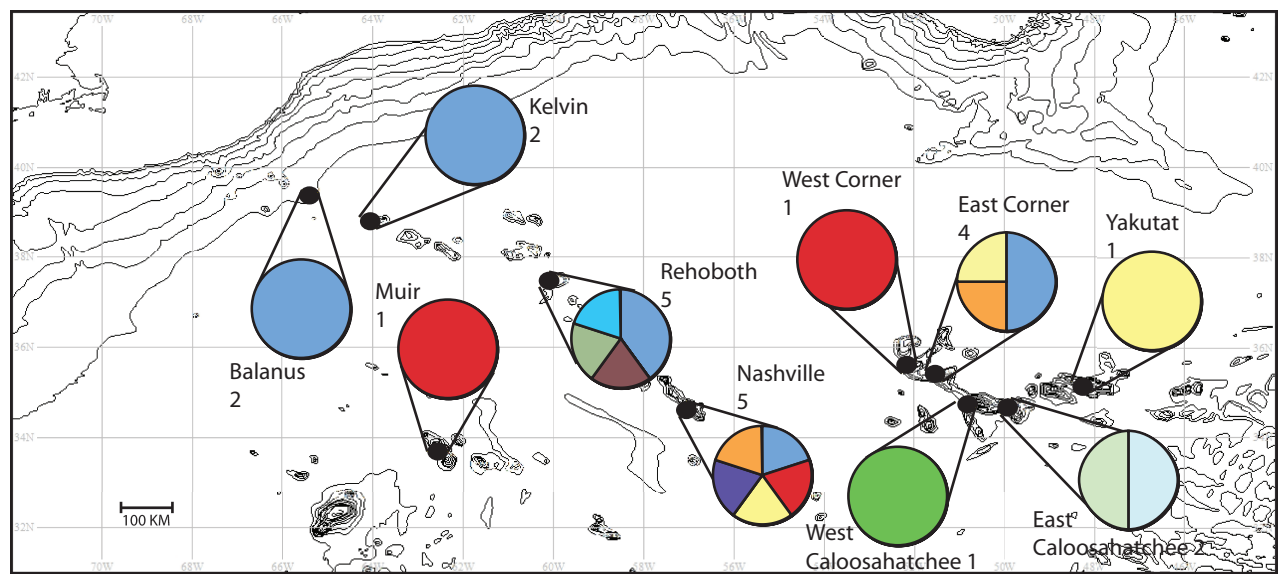

Haplotype 1

- Haplotype 2

$\square$ Haplotype 3
口Haplotype 1 口Haplotype 2

口Haplotype 3

口Haplotype 4

- Haplotype 5

口Haplotype 8

口Haplotype 9

口Haplotype 10

Figure 3. Haplotype map for $O$. oedipus a. $16 \mathrm{~S}$ sequences, b. COI sequences, and c. $16 \mathrm{~S}+\mathrm{COI}$ sequences. Pie graphs indicate haplotypic composition of each location and numbers indicate total number of samples from each location. 
a.

Cho and Shank Figure 4

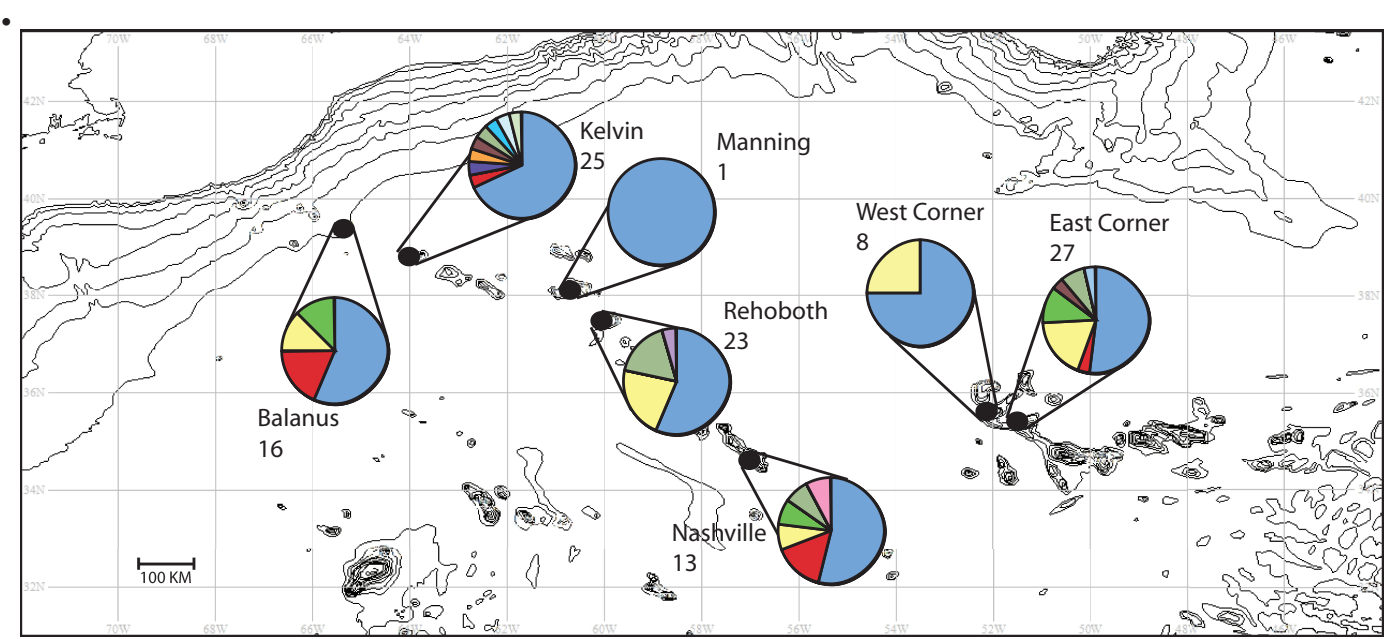

aplotype 1

-Haplotype 2

$\square$ Haplotype 3

Haplotype 4

- Haplotype 5

$\square$ Haplotype 6

- Haplotype 7

口Haplotype 8

पHaplotype 9

DHaplotype 10

口Haplotype 11

$\square$ Haplotype 12

Haplotype 13

-Haplotype 14

口Haplotype 15

b.

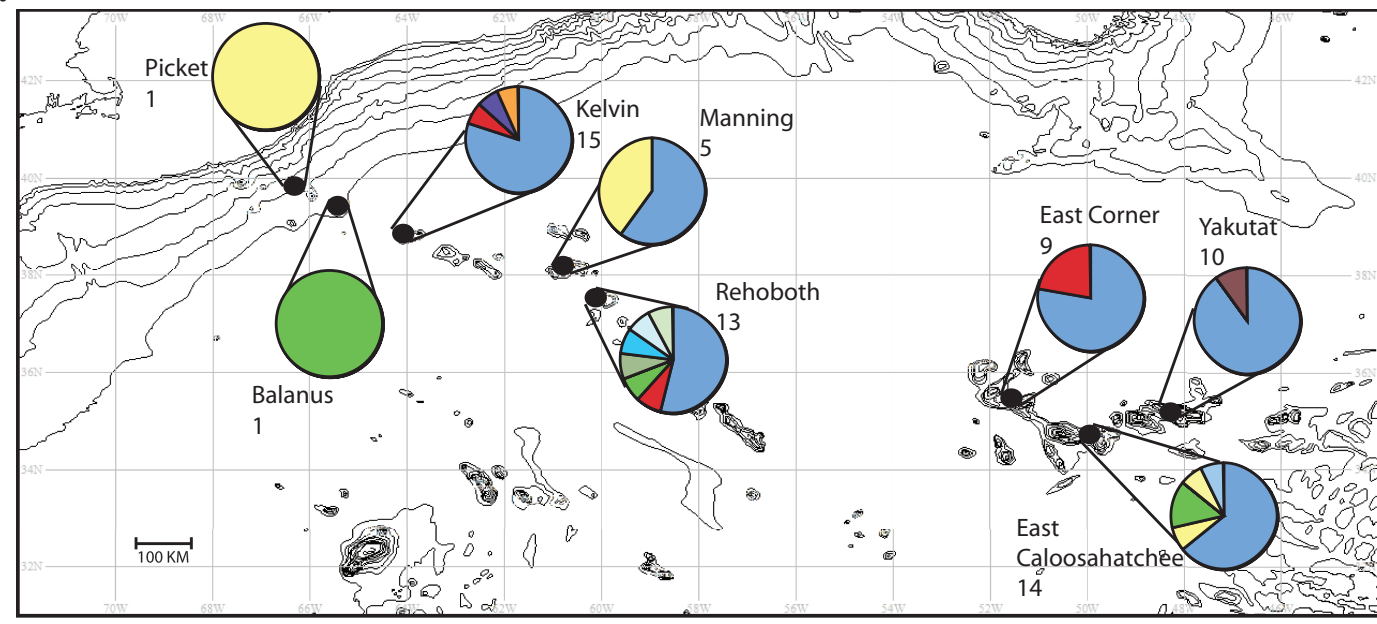

-Haplotype 1

$\square$ Haplotype 2

Haplotype 3

口Haplotype 4

-Haplotype 5

-Haplotype 6

-Haplotype 7

Daplotype 8

Haplotype 9

$\square$ Haplotype 10

Haplotype 11

-Haplotype 12

पHaplotype 13

Figure 4. Haplotype map for a. 16S sequences of $O$. abyssalis and b. 16S sequences of $O$. chelys. Pie graphs indicate haplotypic composition of each location and numbers indicate total number of samples from each location. 

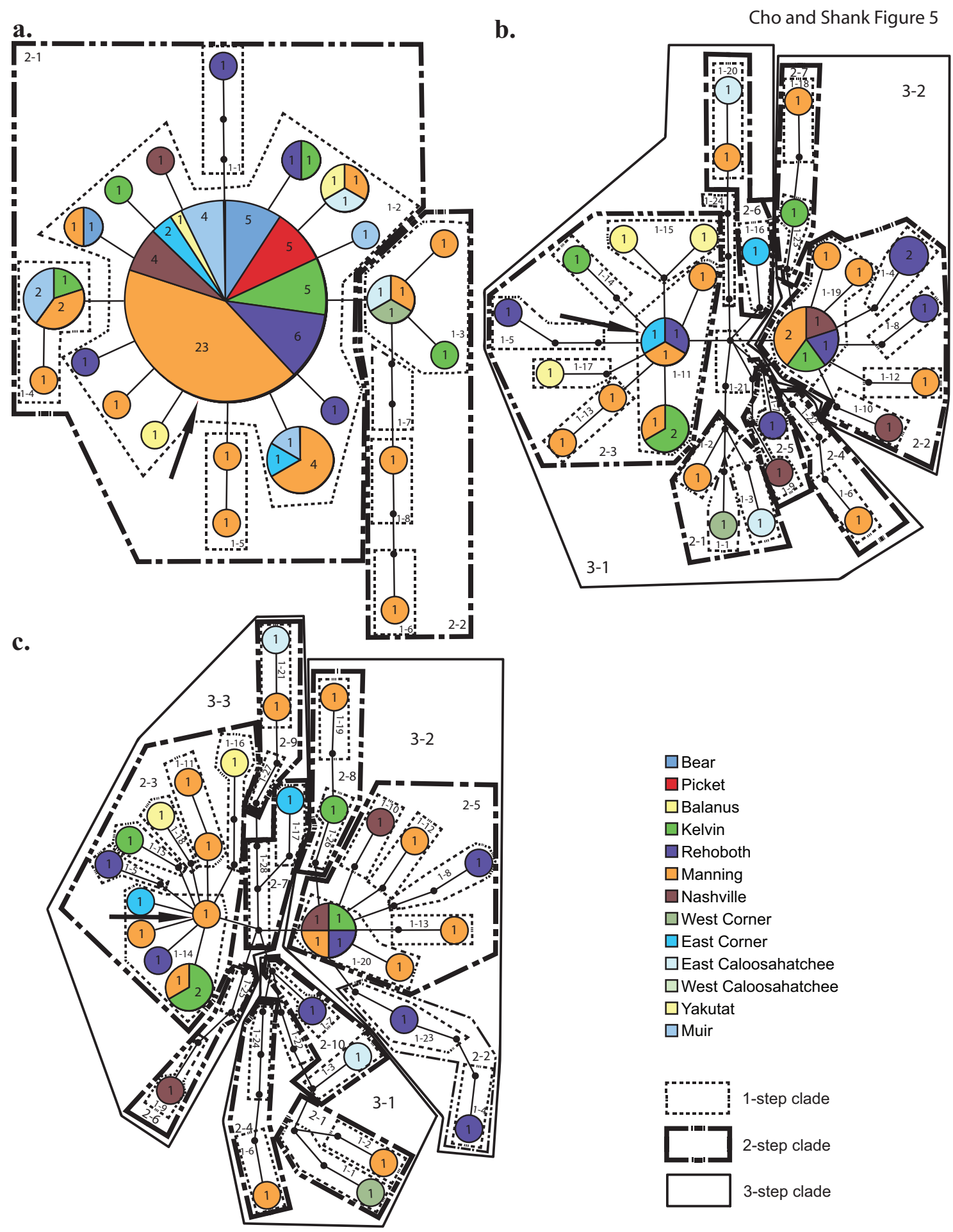

Figure 5. TCS haplotype network for $A$. clavigera a. 16S sequences, b. COI sequences, and c. 16S+COI sequences. Circles represent the different haplotypes observed, with circle areas proportional to the number of individuals possessing that haplotype. Haplotypes shared among geographic locations are further broken down into pie graphs. Connecting lines represent 1 base pair difference and small black circles represent interior node haplotypes not present in the samples. The ancestral haplotype is marked with an arrow. 
a.

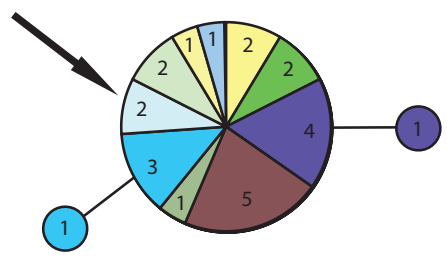

c.

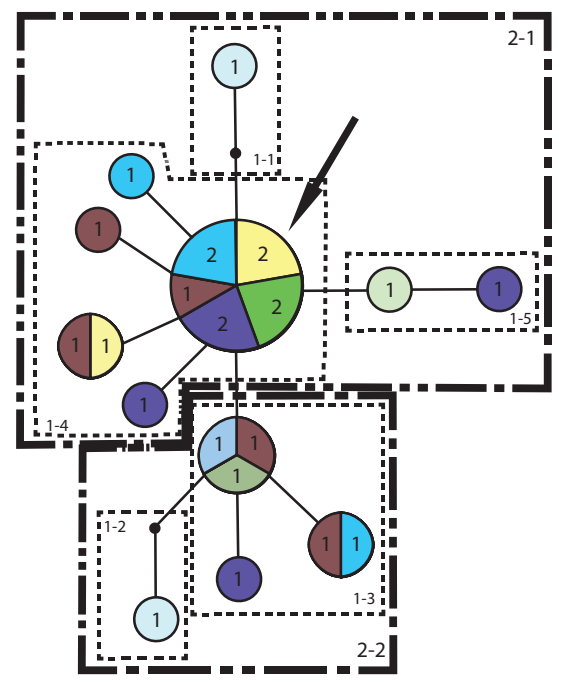

e.

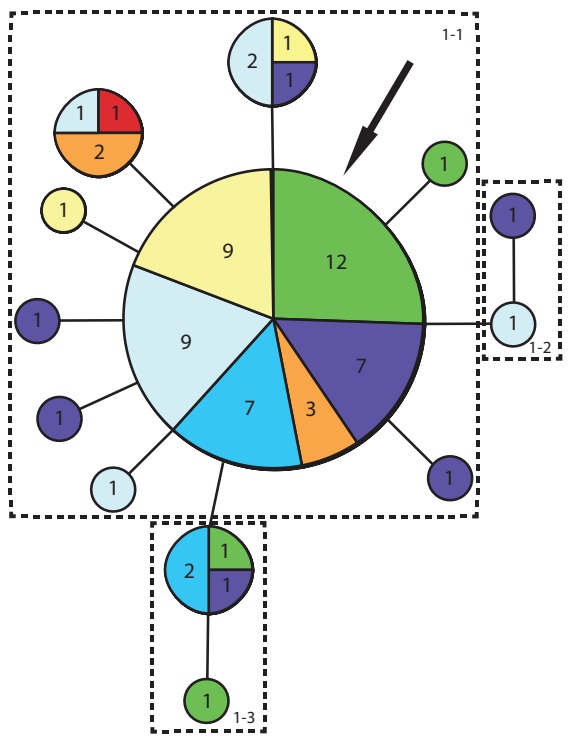

b.

Cho and Shank Figure 6

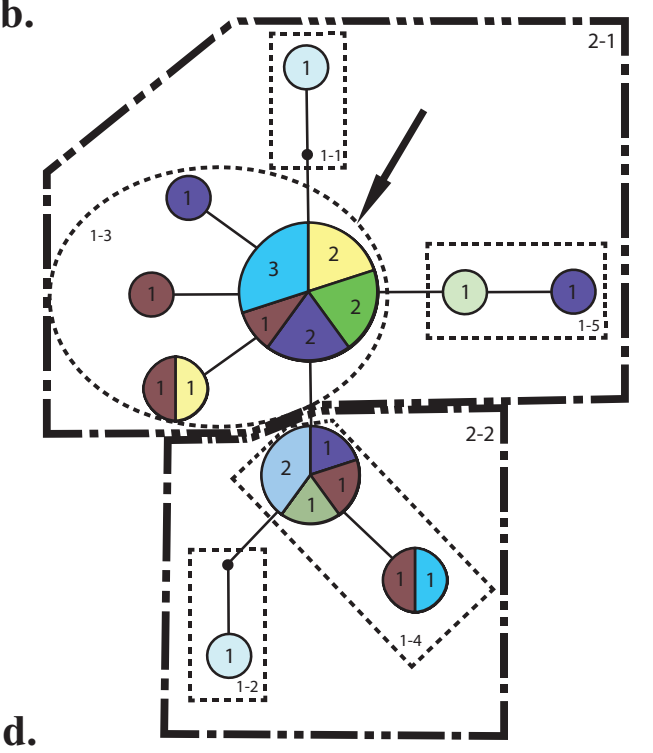

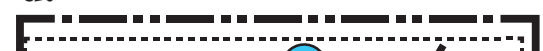

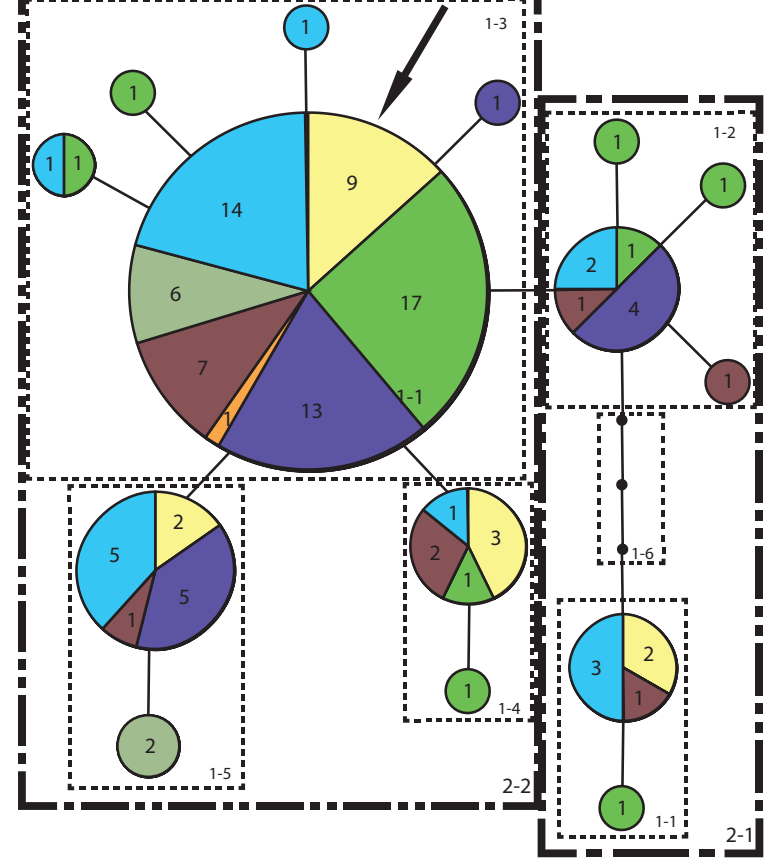

$\square$ Bear

口Picket

$\square$ Balanus

$\square$ Kelvin

$\square$ Rehoboth

$\square$ Manning

$\square$ Nashville

Figure 6. TCS haplotype network for a. O. oedipus $16 \mathrm{~S}$ sequences, b. O. oedipus COI sequences, c. $O$. oedipus $16 \mathrm{~S}+\mathrm{COI}$ sequences, d. O. abyssalis $16 \mathrm{~S}$ sequences, and e. $O$. chelys $16 \mathrm{~S}$ sequences. Circles represent the different haplotypes observed, with circle areas proportional to the number of individuals possessing that haplotype. Haplotypes shared among geographic locations are further broken down into pie graphs. Connecting lines represent 1 base pair difference and small black circles represent interior node haplotypes not present in the samples. The ancestral haplotype is marked with an arrow. 


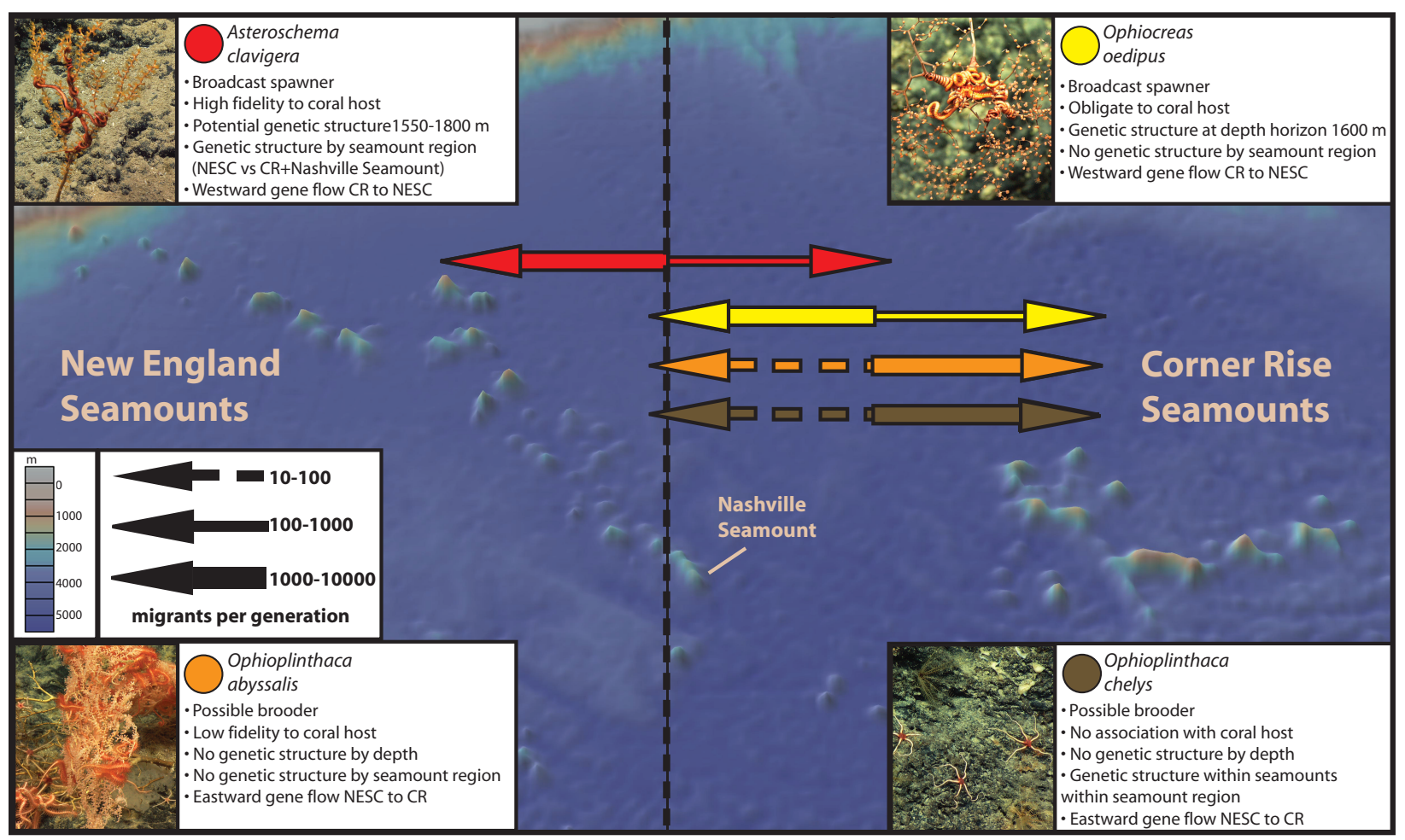

Figure 7. Asymmetrical gene flow estimated as migrants per generation for the $16 \mathrm{~S}+\mathrm{COI}$ datasets of $A$. clavigera and O. oedipus and the $16 \mathrm{~S}$ datasets of $O$. abyssalis and O. chelys. Arrows indicate the asymmetrical direction of inferred historical gene flow from one region to another and magnitudes are indicated by arrow thickness. Colors correspond to species. NESC = New England Seamount Chain; CR $=$ Corner Rise. 